\title{
Perspectives on the Role of Non-Coding RNAs in the Regulation of Expression and Function of the Estrogen Receptor
}

\author{
Mohammad Taheri ${ }^{1}$, Hamed Shoorei ${ }^{2}$, Marcel E. Dinger ${ }^{3, *(\mathbb{D})}$ and Soudeh Ghafouri-Fard ${ }^{4, *(D)}$ \\ 1 Urogenital Stem Cell Research Center, Shahid Beheshti University of Medical Sciences, \\ Tehran 16666-63111, Iran; mohammad.taheri@sbmu.ac.ir \\ 2 Department of Anatomical Sciences, Faculty of Medicine, Birjand University of Medical Sciences, \\ Birjand 9717853577, Iran; Shoorei.h@tbzmed.ac.ir \\ 3 School of Biotechnology and Biomolecular Sciences, University of New South Wales, \\ Sydney, NSW 2052, Australia \\ 4 Department of Medical Genetics, Shahid Beheshti University of Medical Sciences, Tehran 19839-63113, Iran \\ * Correspondence: m.dinger@unsw.edu.au (M.E.D.); s.ghafourifard@sbmu.ac.ir (S.G.-F.)
}

Received: 29 May 2020; Accepted: 27 July 2020; Published: 4 August 2020

\begin{abstract}
Estrogen receptors (ERs) comprise several nuclear and membrane-bound receptors with different tissue-specific functions. ER $\alpha$ and ER $\beta$ are two nuclear members of this family, whereas $G$ protein-coupled estrogen receptor (GPER), ER-X, and Gq-coupled membrane estrogen receptor (Gq-mER) are membrane-bound G protein-coupled proteins. ER $\alpha$ participates in the development and function of several body organs such as the reproductive system, brain, heart and musculoskeletal systems. ER $\beta$ has a highly tissue-specific expression pattern, particularly in the female reproductive system, and exerts tumor-suppressive roles in some tissues. Recent studies have revealed functional links between both nuclear and membrane-bound ERs and non-coding RNAs. Several oncogenic lncRNAs and miRNAs have been shown to exert their effects through the modulation of the expression of ERs. Moreover, treatment with estradiol has been shown to alter the malignant behavior of cancer cells through functional axes composed of non-coding RNAs and ERs. The interaction between ERs and non-coding RNAs has functional relevance in several human pathologies associated with estrogen regulation, such as cancers, intervertebral disc degeneration, coronary heart disease and diabetes. In the current review, we summarize scientific literature on the role of miRNAs and lncRNAs on ER-associated signaling and related disorders.
\end{abstract}

Keywords: lncRNA; miRNA; estrogen receptor; cancer

\section{Introduction}

Estrogen receptors (ER) are classified into two major groups, $E R \alpha$ and $E R \beta$, which are produced by ESR1 and ESR2 genes, respectively. ERs are activated by the estrogen hormone and have specific tissue- and cell-type expression patterns [1]. The activation of ER by estrogen leads to the translocation of ER into the nucleus and subsequent binding with target DNA sequences to alter the expression of certain genes [2]. ER $\alpha$ participates in the development and function of several bodily organs such as the reproductive system, brain, heart and musculoskeletal systems [3]. In addition to the female reproductive system and mammary gland, this type of ER has widespread expression across the body [3,4]. Accordingly, the functions of several organ systems are commonly affected in ER $\alpha$ knockout mice [4]. Most notably, a kind of ligand-independent signaling has been reported for ER $\alpha$, in a manner in which this receptor can be activated by either epidermal growth factor (EGF) or insulin-like growth factor-1 [5,6]. ER $\beta$ is another member of the ER family that, following binding 
to $17-\beta$-estradiol (E2), estriol or similar ligands, makes homodimers or heterodimers with ER $\alpha$. These dimers bind with and activate the transcription of target genes. Notably, a dominant negative effect has been reported for some isoforms of ER $\beta$ that leads to the inhibition of the activity of other ERs [7]. Moreover, the anti-proliferative effect of ER $\beta$ can compete against the functions of $E R \alpha$ in the reproductive system [8]. ER $\beta$ also has a tumor-suppressive role in a variety of cancers, including prostate malignancy [9].

In addition to these nuclear receptors, a number of membrane ERs including GPER, ER-X, and Gq-mER have been recognized that are mainly $\mathrm{G}$ protein-coupled proteins [10]. These receptors stimulate intracellular signaling through the induction of adenylyl cyclase and G-protein-associated release of membrane-linked heparin-bound EGF [11]. These receptors have putative functions in neurons. For instance, ER-X expression has been documented in the neonate cortex. It is also re-activated in the adult brain following ischemic brain stroke [10]. The functions of membrane ER $\alpha$ signaling in response to estrogen are exerted in a highly tissue-dependent manner. For instance, the trabecular bone in the axial skeleton is highly dependent on this pathway, while the effects of estrogen on liver weight and total body fat mass are essentially independent of this pathway [12]. Thus, both nuclear and membrane-bound ERs have various functions in diverse human tissues. Consequently, the dysregulation of their expression can interfere with the physiological conditions of related organs. Figure 1 provides a schematic overview of the estrogen receptor pathway and its key functions.

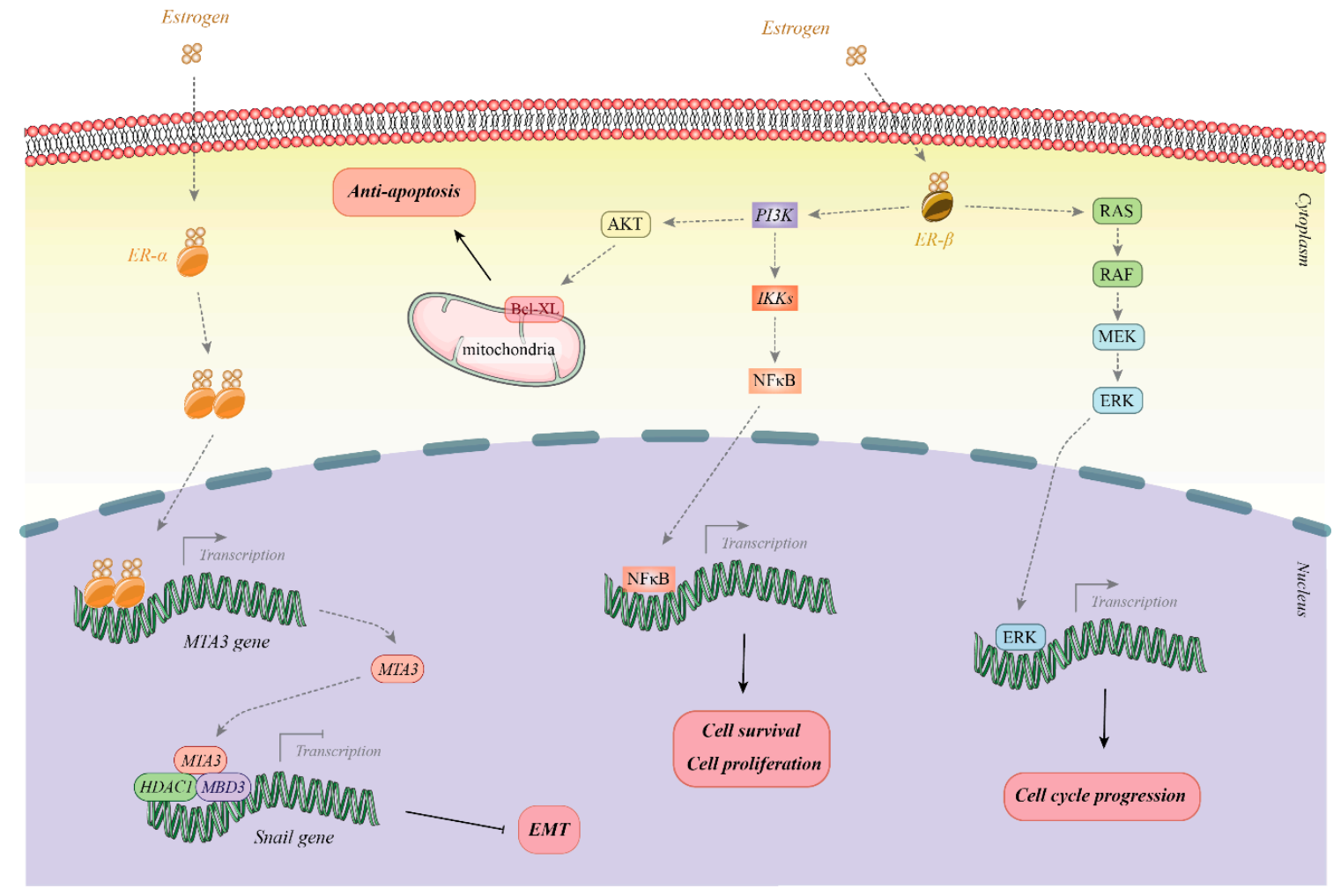

Figure 1. Overview of the estrogen receptor pathway and its key functions. Estrogen can bind with estrogen receptor $(E R \alpha$ or $E R \beta)$ to influence expression and activity of several signaling pathways that regulate cell cycle progression, cell survival and proliferation and epithelial-mesenchymal transition (EMT).

Recent studies have revealed functional associations between different ERs and non-coding RNAs. Several long non-coding RNAs (lncRNAs) and microRNAs (miRNAs), which are abundantly expressed in mammalian genomes, affect or are influenced by ERs. Moreover, a number of studies have indicated associations between circular RNAs (circRNAs) and ERs. LncRNAs are typically 
defined as transcripts larger than 200 nucleotides with no recognizable protein-coding capacity and can interact with various biomolecules including RNA, DNA and proteins. Their regulatory roles in gene expression can be exerted through the modulation of chromosome configuration, the regulation of transcription, splicing, availability and stability of mRNA, and post-translational modifications [13]. miRNAs, which are $\sim 22$ nucleotides in length, mainly function as post-transcriptional regulators of gene expression through mediating the degradation and/or translational suppression of their target mRNAs. In addition, they exert specific functions in the nucleus, such as miRNA-guided transcriptional regulation of gene expression [14]. CircRNAs are mostly produced by the alternative splicing of pre-mRNA. With a specific structure formed by the binding of their $3^{\prime}$ and $5^{\prime}$ ends, they have specific functions in normal development and human disorders, several of which need to be clarified [15]. In the current review, we summarize the scientific literature published to date on the role of noncoding transcripts in ER-associated signaling.

\section{LncRNAs and ER Functions in Cancers}

ER signaling has been implicated in several aspects of tumorigenesis such as cancer initiation, progression and metastasis. ER co-regulatory molecules are differentially expressed in malignant cancers and their activities can be changed during cancer progression [16]. The ER $\alpha$ coregulators Amplified in breast cancer 1 (AIB1) and steroid receptor coactivator (SRC)-1 have been demonstrated to facilitate breast cancer metastasis through the induction of matrix metalloproteinase 2 (MMP2) and MMP9 and twist, respectively $[17,18]$.

Moreover, ER signaling contributes to the stemness properties in the context of cancer. The expression of ER in breast cancer cells has been correlated with the expression levels of cancer stem cell (CSC) markers Gli1 and ALDH1. In addition, E2 has been shown to increase Gli1 expression only in ER-positive breast cancer cells. E2 has enhanced the self-renewal of CSCs as well as possessing invasive properties and epithelial-mesenchymal transition (EMT) in ER-positive/Gli1 positive cells but not in Gli1 knockdown cells. Therefore, estrogen effects on CSCs and EMT are mediated by Gli1 [19]. Moreover, a certain variant of ER, namely ER $\alpha 36$, has been involved in tamoxifen-induced stemness in breast cancer cells. Tamoxifen has a direct interaction with this ER variant which stimulates ER $\alpha 36$ to increase the stemness and metastatic potential of these cells through the activation of Aldehyde Dehydrogenase 1 Family Member A1 (ALDH1A1) [20].

$\mathrm{ER} \alpha$ is among the transcription factors that induce the promoter activity of the insulin-like growth factor receptor (IGFR) gene, leading to the over-expression of IGF-1R and evasion from anti-growth signals [21]. On the other hand, estrogen has been shown to induce apoptosis in several types of cancer cells. Several signaling pathways such as the intrinsic and extrinsic apoptosis pathways, the NF-KB-associated survival pathway and PI3K/Akt axis participate in E2-associated apoptosis [22].

ERs have additional roles in the regulation of immune cell function in the tumor microenvironment. These kinds of receptors are extensively present in several cell types participating in the innate and adaptive immune reaction and modulate cytokines secretion. Investigations conducted in several cancer types, such as carcinomas, being conventionally considered as non-immunogenic cancers, indicate estrogen as a possible mediator of immunosuppression via the regulation of pro-tumor reactions in an independent manner from their effects on tumor cells [23].

Consistent with these diverse roles of ER signaling in carcinogenesis, ER-associated lncRNAs are also involved in several aspects of tumorigenesis. LncRNAs induce several crucial cancer phenotypes via their interactions with numerous biomolecules such as DNA, protein, and RNA [24]. The functions of ER-associated lncRNAs have been assessed in diverse cancers; however, breast cancer has been a particular focus due to the importance of ER signaling in breast tumorigenesis. Both types of nuclear and membrane-bound ERs have been investigated. For instance, the expression of the estrogen-inducible TMPO Antisense RNA 1 (TMPO-AS1) is increased in endocrine therapy-resistant MCF-7 cells compared with its expression in regular MCF-7 cells. This lncRNA enhances the proliferation and survival of ER-positive breast cancer cells. High-throughput studies showed associations between this transcript 
and the estrogen signaling pathway. Mechanistically, TMPO-AS1 regulates ESR1 expression via direct interaction with its mRNA by increasing the stability of the transcript [25].

The activation of GPER by E2 and the GPER-specific agonist G1 GPER has been shown to decrease the expression of lncRNA-Glu [26]. This lncRNA can diminish the function of glutamate transport and the expression of VGLUT2. Thus, GPER-associated decrease in lncRNA-Glu enhances glutamate transport function and the expression of VGLUT2. LncRNA-Glu-VGLUT2 signaling boosts the effects of cAMP-PKA signaling in the production of glutamate in triple-negative breast cancer cells, therefore increasing the invasive and metastatic potential of these cells [26].

The IncRNA in non-homologous end joining pathway 1 (LINP1) is overexpressed in tamoxifen-resistant breast cancer cells [27]. In vitro and in vivo investigations showed that LINP1 silencing decreased resistance to this drug and the viability of resistant breast cancer cells. Moreover, LINP1 silencing enhances apoptosis in these cells after exposure to tamoxifen. On the other hand, LINP1 upregulation enhances cell mobility through influencing the epithelial-mesenchymal transition process. The transcription of this IncRNA is reduced by ER. Both tamoxifen therapy and hormone withdrawal upregulate LINP1. The upregulation of this lncRNA has been associated with reduction in ER levels and the estrogen response, which is an essential element in anti-estrogen resistance. Thus, LINP1 has an important role in tamoxifen resistance and could be a putative target to enhance the efficiency of tamoxifen therapy in breast cancer [27].

An 11-IncRNA signature has been shown to predict the prognosis and probability of recurrence in a cohort of ER-positive breast cancer patients who received tamoxifen [28]. Furthermore, upregulation of lncRNA LINC01116 in breast cancer tissues has been shown to correlate with patient outcome, tumor size and cancer stage. This lncRNA serves as a molecular sponge for miR-145, enhancing the expression of its target gene ESR1. Based on the results of clinical studies, LINC01116 has been suggested as a prognostic marker in breast cancer that influences the progression of this disorder through the modulation of ESR1 expression [29].

The expression of the oncogenic lncRNA H19 has been recognized as a parameter that determines resistance to paclitaxel in ER $\alpha$-positive breast cancer cells, but not in ER $\alpha$-negative cells. This lncRNA reduces paclitaxel-induced cell apoptosis through the suppression of the expression of pro-apoptotic genes Bcl-2-interacting killer (BIK) and NOXA. Notably, H19 has been identified as a downstream target of ER $\alpha$. Thus, modulation of ER $\alpha$ expression can influence H19 expression, thus altering paclitaxel resistance in breast cancer cells. Taken together, the ER $\alpha / \mathrm{H} 19 / \mathrm{BIK}$ axis has been suggested as a key factor in the determination of chemoresistance [30]. The estradiol-induced expression of H19 is also involved in the pathogenesis of papillary thyroid carcinoma. In vitro studies show that estradiol enhances H19 expression through ER $\beta$. In papillary thyroid carcinoma cells, H19 serves as a molecular sponge for miRNA-3126-5p to mutually induce ER $\beta$ expression. Taken together, the ER $\beta-H 19$ positive feedback participates in the maintenance of cancer stem cells in this type of cancer under treatment with estradiol. This axis is suggested as a putative therapeutic target in this type of thyroid cancer [31].

The expression of the lncRNA myocardial infarction associated transcript (MIAT) is increased in ER-positive breast cancer tissues and in the MCF-7 cell line. Diethylstilbestrol has increased MIAT expression in MCF-7 cells in an ER $\alpha$-dependent way. MIAT knockdown reduced diethylstilbestrol (DES)-associated MCF-7 cell proliferation. MIAT has been suggested as a putative biomarker and a possible therapeutic candidate for ER-positive breast cancer [32]. Moreover, the expression of this IncRNA has been elevated in high-grade breast tumors compared to low-grade tumors. This IncRNA was over-expressed in ER-, progesterone receptor (PR)- and Her2-positive breast cancer tissues. MIAT silencing inhibited breast cancer cell proliferation and induced cell cycle arrest. Moreover, THE silencing of MIAT enhanced apoptosis and reduced the migratory potential of these cells. Such, effects were accompanied by THE over-expression of miR-302, miR-150, and THE downregulation of miR-29c [33]. Another high-throughput sequencing study in MCF-7 cells demonstrated estradiol-mediated transcriptional alterations of lncRNAs and their target genes. Moreover, the transcriptional response of lncRNAs to estradiol mostly occurred before their target 
genes [34]. ER $\alpha$-mediated suppression of the MTA1 lncRNA has been shown to reduce the cell proliferation and metastasis of hepatocellular carcinoma [35]. ER $\alpha$ stimulation by estradiol enhances the proliferation of luminal breast cancer cells. In addition, ER $\alpha$ has additional hormone-independent activities to preserve the epithelial features of breast cancer cells. ER $\alpha$ silencing has altered the expression of several genes including 133 Apo-ER $\alpha$-associated lncRNAs.

The most prevalent ApoER-associated lncRNA is DSCAM Antisense RNA 1 (DSCAM-AS1). This IncRNA is expressed in ER $\alpha+$ breast cancer cells, but is absent in pre-neoplastic tissues. Notably, the expression of DSCAM-AS1 has been inversely correlated with EMT markers. DSCAM-AS1 silencing recapitulated the impact of ER $\alpha$ knockdown such as growth arrest and the activation of EMT markers [36].

The upregulation of HOX Transcript Antisense RNA (HOTAIR) in ER-positive breast cancer cells increases cell proliferation, growth and invasion and has been associated with risk of metastasis. Moreover, estradiol can bind with the estrogen response element in the promoter region of this IncRNA. Notably, HOTAIR activity has a crucial role in the induction of ER signaling in malignant cells [37]. Another study in prostate cancer cells revealed opposite functions of metastasis associated lung adenocarcinoma transcript 1 (MALAT1) and HOTAIR in estrogen-associated transcriptional modulation. Treatment of these cells with $17 \beta$-estradiol enhanced HOTAIR recruitment to chromatin but decreased the recruitment of MALAT1. Therefore, the interaction between IncRNAs, estrogens and ERs has a crucial function in the modulation of gene expression in prostate cancer [38].

LncRNAs can modulate both the expression and activity of ER. The expression of HOTAIR has been increased in tamoxifen-resistant breast cancer tissues compared to the primary samples. This IncRNA is directly targeted by ER. ER signaling has been shown to suppress the expression of HOTAIR. Notably, the over-expression of HOTAIR enhances the ER protein level and therefore increases ER's tenancy on the chromatin. This type of interaction facilitates the regulation of downstream genes by ER. HOTAIR also enhances ligand-independent ER functions and participates in tamoxifen resistance [39]. The lncRNA H19 can modulate ER function as it has been shown to suppress the ER-activated Wnt signaling pathway in breast cancer cells [40].

\section{LncRNAs and ER Function in Other Disorders}

Investigations in an animal model (C57BLK/6J mice) of diabetes mellitus have shown the beneficial effects of quercetin as one of the most active materials in grape pomace extract. Diabetes was induced in these mouse models by a high fat diet. Subsequently, the mice were divided into study groups that received quercetin and a control group without any supplementation. Notably, the anti-diabetic effects of this compound have been exerted through activation of the ER $\alpha$ in a pathway which is dependent on the lncRNA suppressor of hepatic gluconeogenesis and lipogenesis (lncSHGL) [41]. The interaction between lncRNAs and ER is also implicated in the pathogenesis of liver steatosis. The expression of NEAT1 is down-regulated in HepG2 cells following knockdown of ER $\alpha$. The $3^{\prime}$ terminal region of nuclear enriched abundant transcript 1 (NEAT1) has been shown to interact with ER $\alpha$ to enhance expression of Aquaporin 7 (AQP7) and subsequently inhibit liver steatosis. Thus, NEAT1 participates in the activation of $E R \alpha$ to modulate AQP7-associated hepatic steatosis [42]. Investigations in ovarian endometriotic tissues have shown the downregulation of the steroid receptor RNA activator 1 (SRA) lncRNA and ER $\alpha$, but over-expression of SRA protein and ER $\beta$ in comparison with normal endometrial tissues. The silencing of SRA1 enhanced ER $\alpha$ levels but decreased ER $\beta$ levels in endometriotic stromal cells. Moreover, SRA1-silencing decreased proliferation and enhanced apoptosis in these cells. Thus, the SRA-mediated regulation of ER in ovarian endometriosis participates in the proliferation of endometriotic stromal cells [43].

Table 1 summarizes the results of studies which assessed the functional link between ERs and lncRNAs in human disorders. 
Table 1. List of dysregulated ER-associated lncRNAs and their functions in disorders.

\begin{tabular}{|c|c|c|c|c|c|c|c|c|c|}
\hline Type of Disease & IncRNA & $\begin{array}{l}\text { Expression } \\
\text { Pattern }\end{array}$ & Human/Animal & $\begin{array}{c}\text { Number of } \\
\text { Clinical Samples }\end{array}$ & Assessed Cell Line & Targets/Regulators & $\begin{array}{l}\text { Signaling } \\
\text { Pathways }\end{array}$ & Function & $\operatorname{Re}$ \\
\hline \multirow{11}{*}{$\begin{array}{l}\text { Breast Cancer } \\
\quad(\mathrm{BCa})\end{array}$} & LINP1 & Up & Mouse & - & $\begin{array}{l}\text { MCF-7, T47D, } \\
\text { TAMR }\end{array}$ & ER, GREB1, PGR & - & $\begin{array}{l}\text { LINP1 by regulating ER expression and ER signaling } \\
\text { promoted tamoxifen resistance in BCa cells. }\end{array}$ & {$[27$} \\
\hline & TMPO-AS1 & Up & Human & $\begin{array}{c}\text { ER+ samples } \\
(n=32) \\
\text { ER-Samples } \\
(n=83)\end{array}$ & $\begin{array}{l}\text { MCF-7, T47D, } \\
\text { LTED, OHTR }\end{array}$ & $\begin{array}{l}\text { ESR1, GREB1, } \\
\text { WISP2 }\end{array}$ & - & $\begin{array}{l}\text { TMPO-AS1by regulating ESR1could promote } \\
\text { hormone-refractory breast cancer progression. }\end{array}$ & {$[25$} \\
\hline & LINC01116 & Up & Human & $\begin{array}{c}64 \text { BCa tissues } \\
\text { and } 30 \text { normal } \\
\text { breast tissues, } \\
\text { GSE54002 dataset }\end{array}$ & $\begin{array}{l}\text { MCF-10A, MCF-7, } \\
\text { HCC38, } \\
\text { MDA-MB-231 }\end{array}$ & $\operatorname{miR}-145$, ESR1 & - & $\begin{array}{l}\text { LINC01116/miR-145/ESR1 axis is involved in the } \\
\text { pathogenesis of breast cancer. }\end{array}$ & {$[29]$} \\
\hline & H19 & Up & Human & - & $\begin{array}{l}\text { MCF-7, ZR-75-1, } \\
\text { MCF-7R, ZR-75-1R }\end{array}$ & BIK, EZH2 & $\mathrm{ER} \alpha$ & $\begin{array}{l}\text { H19 expression was upregulated in paclitaxel } \\
\text { (PTX)-resistant breast cancer cell lines. ER } \alpha / \text { H19-/IK axis } \\
\text { is involved in promoting chemoresistance in BCa. }\end{array}$ & {$[30]$} \\
\hline & LASER1 & Up & Human & $\begin{array}{c}\text { primary } \mathrm{BCa} \\
(n=72) \text { and } \\
\text { late-stage relapse } \\
\text { BCa patients } \\
(n=24)\end{array}$ & T47D & ESR1 & - & $\begin{array}{l}\text { LASERs via interacting with ESR1 could promote } \\
\text { late-stage relapse in breast cancer. }\end{array}$ & {$[44$} \\
\hline & MIR2052HG & Up & Human & TCGA dataset & - & $\begin{array}{l}\text { ER } \alpha, \\
\text { LMTK3 }\end{array}$ & PKC/MEK/ERK/RSK1 & $\begin{array}{l}\text { MIR2052HG via LMTK3 by recruiting EGR1 could } \\
\text { regulate ER } \alpha \text { level and endocrine resistance in } \\
\text { breast cancer. }\end{array}$ & {$[45$} \\
\hline & LINC00707 & Up & Human & TCGA dataset & $\begin{array}{l}\text { MCF-10A, MCF-7, } \\
\text { MCF-10AT }\end{array}$ & $\begin{array}{l}\text { miR-206, } \\
\text { ER } \alpha\end{array}$ & - & $\begin{array}{l}\text { Treatment with acetyl-11-keto- } \beta \text {-boswellic acid (AKBA, } \\
25 \mu \mathrm{M} \text { ) could inhibit breast lesion MCF-10AT cells by } \\
\text { regulating LINC00707/miR-206 to reduce ER } \alpha .\end{array}$ & {$[46]$} \\
\hline & H19 & Up & Human & - & $\begin{array}{l}\text { MDA-MB231, } \\
\text { MCF-7 }\end{array}$ & - & $\begin{array}{l}\mathrm{ER} \beta, \\
\mathrm{ER} \alpha\end{array}$ & $\begin{array}{l}\text { Treatment with E2 }(10 \mathrm{nM}) \text { could regulate luminal } \\
\text { progenitor cell differentiation through the ER/H19 axis. }\end{array}$ & {$[47]$} \\
\hline & Glu & Down & Human & $\begin{array}{l}96 \text { pairs of } \mathrm{BCa} \\
\text { and adjacent } \\
\text { normal tissues }\end{array}$ & $\begin{array}{l}\text { MDA-MB-468, } \\
\text { HCC1806 }\end{array}$ & VGLUT2 & $\begin{array}{l}\text { GPER, } \\
\text { NMDARCaMK/ } \\
\text { MEK-MAPK }\end{array}$ & $\begin{array}{l}\text { Treatment with E2 (100 nM) could downregulate } \\
\text { expression of Glu in MDA-MB-468 and HCC1806 cells. } \\
\text { GPER-regulated lncRNA-Glu trough } \\
\text { NMDAR-CaMK/MEK-MAPK pathway could promote } \\
\text { invasion and metastasis in breast cancer. }\end{array}$ & {$[26]$} \\
\hline & LINC00472 & Down & Human & 525 BCa patients & $\begin{array}{c}\text { MCF-7, T47D, } \\
\text { MDA-MB-231, } \\
\text { Hs578T, SKBR3, } \\
\text { ZR-75-1, 293T, } \\
\text { H-6035 }\end{array}$ & - & $\mathrm{ER} \alpha, \mathrm{NF}-\mathrm{kB}$ & $\begin{array}{l}\text { ER } \alpha / \text { LINC00472 axis via suppressing NF-kB in breast } \\
\text { cancer could inhibit BCa progression. }\end{array}$ & {$[48]$} \\
\hline & RoR & Up & Human & TCGA dataset & MCF-7 & - & ER, MAPK/ERK & $\begin{array}{l}\text { E2-free treatment could upregulate the expression of RoR. } \\
\text { RoR is involved in the pathogenesis of BCa via promoting } \\
\text { MAPK/ERK and activating ER signaling pathways. }\end{array}$ & {$[49]$} \\
\hline
\end{tabular}


Table 1. Cont.

\begin{tabular}{|c|c|c|c|c|c|c|c|c|c|}
\hline Type of Disease & IncRNA & $\begin{array}{c}\text { Expression } \\
\text { Pattern }\end{array}$ & Human/Animal & $\begin{array}{c}\text { Number of } \\
\text { Clinical Samples }\end{array}$ & Assessed Cell Line & Targets/Regulators & $\begin{array}{l}\text { Signaling } \\
\text { Pathways }\end{array}$ & Function & $\operatorname{Re}$ \\
\hline $\begin{array}{l}\text { Papillary Thyroid } \\
\text { Carcinoma (PTC) }\end{array}$ & H19 & Up & Human & $\begin{array}{l}41 \text { pairs of PTC } \\
\text { and adjacent } \\
\text { normal tissues }\end{array}$ & TPC-1, K-1, 293T & - & $E R \beta$ & $\begin{array}{l}\text { Treatment with E2 could promote H19 transcription via } \\
\text { ER } \beta \text { in PTC cells. ER } \beta / H 19 \text { axis could promote cancer } \\
\text { stem-like properties in PTC. }\end{array}$ & {$[31]$} \\
\hline Liver steatosis & NEAT1 & Up & Human & - & HepG2 & $\mathrm{AQP7}$ & $E R \alpha$ & $\begin{array}{l}\text { NEAT1 could promote steatosis via enhancement of } \\
\text { ER } \alpha \text {-mediated AQP7 expression in HepG2 cells. }\end{array}$ & {$[42]$} \\
\hline $\begin{array}{l}\text { Hepatocellular } \\
\text { Carcinoma (HCC) }\end{array}$ & MTA1 & Down & Mouse & & $\begin{array}{l}\text { HepG2, Нер3B, } \\
\text { Hep3B-ER } \alpha\end{array}$ & - & $\mathrm{ER} \alpha$ & $\begin{array}{l}\text { Treatment with E2 }(100 \mathrm{nM}) \text { could downregulate the } \\
\text { expression of MTA1 in Hep3B cells. ER } \alpha \text { by inhibiting } \\
\text { MTA1 could protect HCC from proliferation } \\
\text { and metastasis }\end{array}$ & {$[35$} \\
\hline $\begin{array}{l}\text { Type } 2 \text { Diabetes } \\
\text { Mellitus (T2DM) }\end{array}$ & LncSHGL & Up & Mouse & & $\begin{array}{l}\text { HepG2, 293T, } \\
\text { NCTC-149 }\end{array}$ & $\mathrm{ER} \alpha$ & - & $\begin{array}{l}\text { Treatment with quercetin }(100 \mathrm{mg} / \mathrm{kg}) \text { via promoting } \\
\text { IncSHGL through ER } \alpha \text { could suppress the complications } \\
\text { of T2DM. }\end{array}$ & {$[41]$} \\
\hline $\begin{array}{c}\text { Renal Cell } \\
\text { Carcinoma (RCC) }\end{array}$ & HOTAIR & Up & Human & TCGA dataset & $\begin{array}{l}\text { 786-O, A498, } \\
\text { ACHN, Caki-1 }\end{array}$ & $\begin{array}{c}\text { miR-138, } \\
\text { miR-200c, } \\
\text { miR-204, miR-217, } \\
\text { ADAM9, CCND2, } \\
\text { EZH2, VEGFA, } \\
\text { VIM, ZEB1, ZEB2 }\end{array}$ & $E R \beta$ & $\begin{array}{l}\text { ER } \beta \text { via regulating HOTAIR-miR-138/200c/204/217 } \\
\text { associated ceRNA network could promote } \\
\text { RCC progression. }\end{array}$ & {$[50]$} \\
\hline
\end{tabular}




\section{4. miRNAs and ER Function in Cancers}

Several ER-associated miRNAs have been dysregulated in cancer. In addition, miRNAs can participate in the anti-proliferative effects of therapeutic compounds. For instance, treatment of ER $\alpha$-positive breast cancer cells with the O-methylated isoflavone biochanin A can enhance the expression of miR-375. This compound influences a feedback loop between miR-375 and $\mathrm{ER} \alpha$, thus enhancing the proliferation of breast cancer cells [51]. Moreover, low concentrations of formononetin have been shown to enhance the proliferation of ER $\alpha$-positive cells human umbilical vein endothelial cells (HUVEC) and MCF-7. Formononetin increases the expression of ER $\alpha$, miR-375, p-Akt, and Bcl-2. Thus, this agent induces the proliferation of ER $\alpha$-positive cells via the induction of miR-375 expression through a miR-375/ER $\alpha$ feedback loop [52]. The ER $\alpha$-miR-375-PTEN-ERK1/2-bcl-2 axis is also involved in the effects of this substance in the enhancement of the proliferation of CNE2 cells [53]. Curcumin has induced apoptosis in osteosarcoma cells through the induction of the miR-125a/ERR $\alpha$ signaling pathway [54]. Calycosin has been shown to stimulate apoptosis in colorectal cancer cells, by modulating the ER $\beta / \mathrm{miR}-95$ and IGF-1R, PI3K/axes [55]. On the other hand, myocardin suppresses the ER $\alpha$-associated proliferation of MCF-7 cells by interfering with ER-associated transcriptional induction, mostly via the suppression of the ER $\alpha$ function. Notably, myocardin promotes the expression of miR-885, a miRNA that inhibits the translation of E2F1 [56].

A number of miRNAs have been shown to alter the expression of ER or other genes participating in the associated pathways. High-throughput sequencing of the transcriptome of the MCF-7 cell line showed increased expression of miR-335-5p and miR-335-3p. These miRNAs suppress the expression of genes participating in the ER $\alpha$ signaling pathway and confer tomoxifen-resistance in these cells. Therefore, although miR-335 has been regarded as a tumor suppressor miRNA, it exerts an oncogenic effect by enhancing agonistic estrogen signaling in the context of cancer [57]. The over-expression of miR-206, miR-133a, and miR-27b has suppressed the proliferation and migration of MCF-7 cells. Such tumor-suppressive effects of these miRNAs were exerted through the modulation of ER $\alpha$ and Aryl Hydrocarbon Receptor (AhR) signaling pathways. Thus, these miRNAs have been suggested as promising prognostic biomarkers and therapeutic targets in breast cancer [58]. Expression of miRNAs vary in association with the invasiveness of breast cancer cells. For instance, expressions of miR-221 and miR-222 in in situ tumors were inversely correlated with ER. However, in pure invasive breast cancer cells, there was a positive correlation between the expression of these miRNAs and TIMP3 expression. Thus, the enhancement of expressions of miR-221/222 may be a critical occurrence in the development of in situ carcinomas. These miRNAs underscore the putative differences between different types of breast cancer [59]. The ER $\alpha$-miR-1271-SNAI2 axis is involved in the regulation of transforming growth factor (TGF)- $\beta$-induced breast cancer progression [60]. miR-301a-3p and miR-129 have been shown to inhibit estrogen signaling through direct interaction with ESR1 and ESR2 genes, respectively [61,62]. In addition, miR-148a and miR-22 inhibit ESR1 expression to inhibit the viability and migration of breast cancer cells $[63,64]$. miR-142-3p has also been identified as an inhibitor of ESR expression in ER-positive breast cancer cells [65]. The regulation of ESR1 expression by miR-135b has implications in the pathogenesis of breast and prostate cancer [66]. On the other hand, decreased levels of miR-497 participate in the cell proliferation, migration, and invasion of ER-negative breast cancer by targeting ER $\alpha$ [67]. Conversely, miR-203 suppresses the estrogen-induced viability, migration and invasion of $E R \alpha$-positive breast cancer cells [68]. miR-107-5p has a direct interaction with ESR1 to enhance the proliferation and invasion of endometrial carcinomas [69]. On the other hand, miR-195 suppresses epithelial-mesenchymal transition by targeting G protein-coupled ESR1 in endometrial carcinomas [70]. In hepatocellular carcinomas (HCCs), HBx protein-associated induction of miR-221 enhances the proliferation of cancer cells by targeting ER $\alpha$ [71]. miR-1280 has been implicated in the pathogenesis of thyroid carcinomas by targeting ER $\alpha$ [72]. miR-181a-5p has been identified as a mediator of ER $\beta$-associated suppression of cholesterol production in triple-negative breast cancer [73]. ER-mediated miR-486-5p modulation of Olfactomedin 4 (OLFM4) is also implicated in ovarian cancer [74]. Importantly, miR-320a and miR-451a have been shown to sensitize tamoxifen-resistant 
breast cancer cells to this agent by targeting ERR $\gamma$ and 14-3-3ろ, ER $\alpha$, and autophagy, respectively $[75,76]$. Moreover, miR-27a and miR-125a-3p sensitize breast cancer cells to endocrine therapy [77,78]. On the other hand, miR-1271 participates in letrozole resistance through the inhibition of ER $\alpha$ expression [79]. Finally, the ER $\alpha / \mathrm{miR}-124 / \mathrm{AKT} 2$ axis is involved in the pathogenesis of breast cancer [80].

Meanwhile, ERs have also been observed to affect the expression of miRNAs. For example, E2 has been shown to enhance the expression of miR-199a-3p in triple-negative breast cancer cells [81]. Moreover, E2 alters the expression of 114 miRNAs in HUVEC cells. These miRNAs have been enriched in cell death and survival, lipid metabolism and reproductive system function [82]. ER $\alpha$-mediated upregulation of miR-590 alters the expression of FAM171A1, which contributes to breast cancer invasiveness [83]. Moreover, miR-27a/b and miR-494 participate in the estrogen-mediated down-regulation of the expression of tissue factor pathway inhibitor $\alpha$ [84]. Dehydroepiandrosterone induction of G-protein-coupled ER has enhanced miR-21 expression in human HCC [85]. ESR $\beta$ has been shown to enhance bladder cancer growth and invasion through the modulation of the miR-92a/DAB2IP axis [86]. The expression of miR-338-3p is modulated by estrogen through GPER in breast cancer cells [87].

ER $\beta$ has also been shown to modulate the expression of miRNAs. The downregulation of ER $\beta$ in MDA-MB-231 breast cancer cells significantly alters the miRNA profile, especially the levels of miR-10b, miR-200b and miR-145. Further experiments showed that the specific effect of estradiol on miRNA signature is determined by the ER status of breast cancer cells. miR-10b and miR-145 have been shown to modulate the EMT process and function of principal matrix molecules that participate in breast cancer aggressiveness. The inhibition of ER $\beta$ in MDA-MB-231 cells induces changes in cell behavior and in extracellular matrix proteins in association with the modulation of the miRNA profile. Interfering with the ER $\beta$-modulated miR- $10 \mathrm{~b}$ and miR- 145 has been suggested as a putative approach to detect and treat breast cancer [88]. Moreover, ER $\beta$ has been shown to decrease colon cancer metastasis via the miR-205-PROX1 axis [89].

The expression of miR-21 has been shown to be negatively correlated with the expression of ER [90], yet the details of the interaction between this miRNA and ER have not been elucidated.

miRNAs can regulate both the expression and activity of ER. For instance, miR-1, miR-9, miR-18a/b, $\mathrm{miR}-19 \mathrm{a} / \mathrm{b}, \mathrm{miR}-20 \mathrm{a} / \mathrm{b}$ and miR-22 directly target the ESR gene to suppress its expression [91]. In addition, miRNAs can alter ER activity. For instance, miR-22 can also indirectly suppress ER $\alpha$ activity via the inhibition of the function of the ER $\alpha$ transcriptional coactivator, Sp1 [92]. Moreover, miR-206 has been predicted to target ER $\alpha$ coactivators Nuclear Receptor Coactivator 1 (NCOA1)/SRC1 and NCOA3/SRC3 [93].

\section{5. miRNAs and ER Function in Other Disorders}

A variety of studies have associated miRNA activity with ER function. For example, miR-320a has been found to be upregulated in the placental samples of preeclamptic patients and over-expression of this miR-320a inhibits trophoblast invasion [94]. This miRNA targets estrogen-related receptor gamma (ERR $\gamma$ ) and inhibits its transcription and translation. Thus, miR-320a upregulation leads to abnormal placentation by regulating ERR $\gamma$ [94]. This miRNA has established roles in the proliferation, migration, invasion, and apoptosis of both trophoblasts and endothelial cells through modulation of this receptor [95]. Furthermore, the interactions between ER and miRNAs have been implicated in the pathogenesis of intervertebral disc degeneration (IDD). A comparison between normal and degenerated human cartilaginous endplates (CEP) tissues from individuals with idiopathic scoliosis and IDD, respectively, revealed lower levels of aggrecan, collagen II, TGF- $\beta$ and ER $\alpha$, but higher amounts of MMP-3, adamts-5, IL- $1 \beta$, TNF- $\alpha$, IL-6, and miR-221 in degenerated CEP tissues. E2 was shown to upregulate the expression of aggrecan and collagen II, and the production of TGF- $\beta$ in degenerated CEP, thus protecting these cells from degeneration. Functional studies confirmed the direct interaction between ER $\alpha$ and miR-221. This miRNA may weaken the shielding influences of E2 in degenerated CEP cells via the inhibition of ER $\alpha$ [96]. miR-203-3p has been shown to be over-expressed 
in the nucleus pulposus (NP) tissues of high-grade IDD patients compared with low-grade IDD patients. Notably, the expression of this miRNA has been negatively correlated with ER $\alpha$ expression. miR-203-3p has been shown to directly target ER $\alpha$ in the NP cells of IDD patients [97]. The role of miR-203 in the regulation of ER $\alpha$ and cartilage degradation in IL-1 $\beta$-stimulated chondrocytes has been verified in another study [98]. The suppression of miR-203 expression has improved osteoarthritis cartilage degradation in an animal model [99]. A number of miRNAs such as miR-26b-3p are involved in the regulation of osteoblast differentiation [100]. The expression of miR-92 has been inversely correlated with ER $\beta 1$ expression in the uterosacral ligaments of females with pelvic organ prolapse (POP) [101]. A number of dysregulated miRNAs in myasthenia gravis patients, namely miR-21-5p, let-7a, and let 7f, have been shown to have ESR1-binding sites [102] implying the role of ER signaling in this autoimmune disorder. ER-associated miRNAs are also involved in trophoblast invasion. The inhibition of miR-18a expression has suppressed the invasion and enhanced the apoptosis of human trophoblast cells by targeting the ESR1 gene [103]. miR-18a also participates in the pathogenesis of coronary heart disease via targeting ER [104]. The suppression of miR-148a has been shown to protect against ovariectomy-associated osteoporosis by modulation of ER $\alpha$ [105]. The suppression of miR-181a protects against transient focal cerebral ischemia by targeting ER $\alpha$ in the astrocytes [106]. miR-26b-3p participates in the regulation of the proliferation of mesenchymal stem cells by targeting the ESR-CCND1 axis [107].

Tables 2 and 3 summarize the functions of up- and downregulated ER-associated miRNAs in human disorders. 
Table 2. List of upregulated ER-associated miRNAs in disorders.

\begin{tabular}{|c|c|c|c|c|c|c|c|c|}
\hline Diseases & microRNA & Human/Animal & Number of Clinical Samples & Assessed Cell Line & Targets/Regulators & $\begin{array}{l}\text { Signaling } \\
\text { Pathways }\end{array}$ & Function & Ref \\
\hline \multirow{8}{*}{$\begin{array}{l}\text { Breast Cancer } \\
\text { (BCa) }\end{array}$} & miR-375 & Mouse & - & T47D, MCF-7 & $\mathrm{ER} \alpha, \mathrm{Bcl}-2$ & - & $\begin{array}{l}\text { Treatment with biochanin A }(2-6 \mu \mathrm{M}) \text { could } \\
\text { upregulate the expression of miR-375 in ER } \alpha+\mathrm{BCa} \\
\text { cells. Biochanin A by affecting a feedback loop of } \\
\text { miR-375 and ER } \alpha \text { could promote the proliferation of } \\
\text { BCa cells. }\end{array}$ & [51] \\
\hline & miR-375 & Mouse & - & HUVEC, MCF-7 & $\mathrm{ER} \alpha, \mathrm{Bcl}-2$ & Akt & $\begin{array}{l}\text { Treatment with formononetin }(2-6 \mathrm{mM}) \text { could } \\
\text { increase the expression of miR-375. Therefore, } \\
\text { formononetin by affecting a feedback loop of miR-375 } \\
\text { and ER } \alpha \text { could promote the proliferation of } \\
\text { ER } \alpha \text {-positive cell. }\end{array}$ & [52] \\
\hline & miR-885 & Human & - & $\begin{array}{c}\text { MCF-7, } \\
\text { MDA-MB-231 }\end{array}$ & $\mathrm{ER} \alpha, \mathrm{E} 2 \mathrm{~F} 1, \mathrm{PCNA}$ & - & $\begin{array}{l}\text { Myocardin via affecting miR- } 885 \text { by ER } \alpha \text { could inhibit } \\
\text { ER } \alpha \text {-mediated proliferation of breast cancer MCF- } 7 \text {. }\end{array}$ & [56] \\
\hline & $\begin{array}{c}\text { miR-27a/b, } \\
\text { miR-494 }\end{array}$ & Human & - & $\begin{array}{l}\text { MCF-7, } \\
293 \mathrm{~T}\end{array}$ & $\mathrm{ER} \alpha$, TFPI $\alpha$ & - & $\begin{array}{l}\text { Treatment with 17a-ethinylestradiol (EE2, } 100 \mathrm{nM} \text { ) } \\
\text { could upregulate the expression miR-27a/b and } \\
\text { miR-494 through ER } \alpha \text { in MCF7 cells. Then, } \\
\text { mentioned-miRs via targeting TFPI } \alpha \text { could be } \\
\text { involved in the pathogenesis of BCa. }\end{array}$ & [84] \\
\hline & $\begin{array}{l}\text { miR-335-5p, } \\
\text { miR-335-3p }\end{array}$ & Human & - & $\begin{array}{c}\text { MCF-7, Hs578t } \\
\text { MCF-7-TR, } \\
\text { MCF-7-FR, } \\
\text { MDA-MB-231, BT-549, } \\
\text { MDA-MB-157, }\end{array}$ & $\mathrm{ER} \alpha$ & - & $\begin{array}{l}\text { miR-335 via inhibiting ER } \alpha \text { could promote tamoxifen } \\
\text { resistance in BCa cells. }\end{array}$ & [57] \\
\hline & $\begin{array}{l}\text { miR-221, } \\
\text { miR-222 }\end{array}$ & Human & $\begin{array}{l}\text { Non-transformed breast tissue } \\
(n=5), \text { in situ carcinoma }(n=19), \\
\text { invasive } \mathrm{BCa} \text { associated with } \\
\text { non-invasive } \mathrm{BCa}(n=12), \\
\text { pure invasive } \mathrm{BCa}(n=27)\end{array}$ & - & ER, TIMP3 & - & $\begin{array}{l}\text { miR-221/222 via ER/TIMP3 axis could be involved in } \\
\text { the pathogenesis of BCa. }\end{array}$ & [59] \\
\hline & miR-10b & Human & - & $\begin{array}{c}\text { MCF-7, } \\
\text { MDA-MB-231 }\end{array}$ & $\begin{array}{c}\text { ER } \beta, \text { MMP2, } \\
\text { MMP7, MMP9, } \\
\text { ECM, syndecan-1 }\end{array}$ & ERK1/2 & $\begin{array}{c}\text { In estrogen-free medium, the expression of miR-10b } \\
\text { was increased in MCF-7 cells. ER } \beta \text { is as an epigenetic } \\
\text { mediator of miR-10b to target EMT and ECM in } \\
\text { mammary cancer. }\end{array}$ & [88] \\
\hline & $\begin{array}{l}\text { miR-206, } \\
\text { miR-27b, } \\
\text { miR-133a }\end{array}$ & Human & - & MCF-7 & $\mathrm{ER} \alpha, \mathrm{AhR}$ & - & $\begin{array}{l}\text { In the ER } \alpha \text { silencing cell relative to scrambled, the } \\
\text { expression of mentioned-miRs is increased. The } \\
\text { forced increased expression of mentioned-miRs via } \\
\text { targeting the ER } \alpha \text { and AhR could suppress MCF-7 } \\
\text { cell proliferation and migration. }\end{array}$ & {$[58]$} \\
\hline
\end{tabular}


Table 2. Cont

\begin{tabular}{|c|c|c|c|c|c|c|c|c|}
\hline Diseases & microRNA & Human/Animal & Number of Clinical Samples & Assessed Cell Line & Targets/Regulators & $\begin{array}{l}\text { Signaling } \\
\text { Pathways }\end{array}$ & Function & Ref \\
\hline \multirow{6}{*}{$\begin{array}{l}\text { Breast Cancer } \\
\text { (BCa) }\end{array}$} & miR-301a-3p & $\begin{array}{l}\text { Mouse and } \\
\text { human }\end{array}$ & $\begin{array}{c}\text { ER+/PR+/HER2+, } \\
\text { ER-/PR-/HER2+, } \\
\text { ER-/PR-/HER2-, } \\
\text { and ER+/PR+/HER2- samples } \\
(n=111)\end{array}$ & $\begin{array}{l}\text { ZR-751, MCF7, T47D, } \\
\text { BT474, MCF10A }\end{array}$ & ESR1 & - & $\begin{array}{l}\text { miR-301a-3p upregulated in cancer stem-like cells. } \\
\text { miR-301a-3p is able to suppress the ER signaling by } \\
\text { directly inhibiting ESR } 1 \text { in the ER+ BCa cells in vitro } \\
\text { and in vivo. }\end{array}$ & [61] \\
\hline & miR-590-5p & Human cell line & - & $\begin{array}{c}\text { MCF-7, T47D, } \\
\text { MDA-MB-231, } \\
\text { SKBR3, BT549, ZR-75, } \\
\text { Hs-578T, HCC1937, } \\
\text { MCF10A, } \\
\text { SUM 149, } \\
\text { SUM 159 }\end{array}$ & FAM171A1 & $\mathrm{ER} \alpha$ & $\begin{array}{l}\text { Loss of ER } \alpha / \mathrm{miR}-590-5 \mathrm{p} \text { axis via upregulating } \\
\text { FAM171A1 resulted in the aggressiveness of } \\
\text { triple-negative breast cancer (TNBC) cells. }\end{array}$ & [83] \\
\hline & $\mathrm{miR}-21$ & Human & $\begin{array}{l}\text { BCa samples }(n=75) \text { including } \\
\text { luminal A, luminal B(HER2 }+ \text {, } \\
\text { luminal B(HER2-), basal-like } \\
\text { type, and HER2 positive }\end{array}$ & - & ER, PR, HER2 & - & $\begin{array}{l}\text { miR-21 was upregulated in Basal-like and HER2 } \\
\text { positive BCa types. miR-21/ER axis is involved in the } \\
\text { pathogenesis of BCa. }\end{array}$ & [90] \\
\hline & miR-206 & Human & $\begin{array}{l}\text { BCa samples }(n=75) \text { including } \\
\text { luminal A, luminal B(HER2 }+ \text {, } \\
\text { luminal B(HER2-), basal-like } \\
\text { type, and HER2 positive }\end{array}$ & - & ER, PR, HER2 & - & $\begin{array}{l}\text { miR-206 was upregulated in Luminal A and B types } \\
\text { of BCa. miR-206/ER axis is involved in the } \\
\text { pathogenesis of BCa. }\end{array}$ & [90] \\
\hline & miR-199a-3p & Human cell line & - & $\begin{array}{l}\text { HCC1806, HCC1937, } \\
\text { MDA-MB-231, } \\
\text { HMEC-184 }\end{array}$ & $\begin{array}{c}\text { GPER, YAP1, } \\
\text { LATS1, } \\
\text { E-cadherin, } \\
\text { N-cadherin, } \\
\text { Vimentin, VEGFA, } \\
\text { AngII }\end{array}$ & Hippo & $\begin{array}{l}\text { Treatment with G-1 G-1(1-[4-(-6-bromobenzol } \\
\text { diodo-5-yl)-3a,4,5,9b } \\
\text { tetrahidro3H5cyclopenta[c]quinolin-8yl]-ethanone) }(1 \\
\mu \mathrm{M}, 48 \mathrm{~h} \text { ) and E2 (10 nM, } 8 \mathrm{~h} \text { ) increased the } \\
\text { expression of miR-199a-3p in MDA-MB-231 cells. The } \\
\text { activation of GPER by regulating miR-199a-3p/CD151 } \\
\text { axis could inhibit EMT process and proliferation, } \\
\text { migration, and invasion of BCa cells. }\end{array}$ & [81] \\
\hline & miR-181a-5p & Human & $\begin{array}{l}\mathrm{ER} \beta+(n=12) \text { and } \mathrm{ER} \beta-(n=32) \\
\text { primary TNBC biopsies }\end{array}$ & $\begin{array}{c}\text { HCC1806, } \\
\text { MDA-MB-468, Hs 578T }\end{array}$ & ER $\beta$ & - & $\begin{array}{l}\text { miR-181a-5p/ER } \beta \text { axis is involved in suppressing of } \\
\text { cholesterol biosynthesis in triple-negative } \\
\text { breast cancer. }\end{array}$ & [73] \\
\hline Preeclampsia & miR-320a & Human & $\begin{array}{l}\text { Placentas from preeclampsia } \\
\text { patient and healthy controls } \\
\qquad(n=18 / \text { each })\end{array}$ & HTR-8/SVneo & $\mathrm{ERR} \gamma$ & - & $\begin{array}{l}\text { miR-320a by targeting ERR } \gamma \text { could inhibit } \\
\text { trophoblast cell invasion. }\end{array}$ & [94] \\
\hline $\begin{array}{l}\text { Myasthenia } \\
\text { Gravis (MG) }\end{array}$ & miR-21-5p & Human & $\begin{array}{l}\text { MG patients without } \\
\text { immunosuppression }(n=37), \\
\text { MG patients with } \\
\text { immunosuppression }(n=14), \\
\text { normal controls }(n=27)\end{array}$ & $\begin{array}{l}\text { GM12878, H1-hESC, } \\
\text { HeLa-S3, HepG2, } \\
\text { HSMM, HUVEC, K562, } \\
\text { NHEK, NHLF }\end{array}$ & $\begin{array}{l}\text { ER, } \\
\text { FOXO }\end{array}$ & NF-kB & $\begin{array}{l}\text { miR-21-5p/ER axis is involved in the pathogenesis } \\
\text { of MG. }\end{array}$ & {$[102]$} \\
\hline
\end{tabular}


Table 2. Cont

\begin{tabular}{|c|c|c|c|c|c|c|c|c|}
\hline Diseases & microRNA & Human/Animal & Number of Clinical Samples & Assessed Cell Line & Targets/Regulators & $\begin{array}{l}\text { Signaling } \\
\text { Pathways }\end{array}$ & Function & Ref \\
\hline \multirow{2}{*}{$\begin{array}{l}\text { Intervertebral } \\
\text { disc } \\
\text { degeneration } \\
\text { (IDD) }\end{array}$} & $\operatorname{miR}-221$ & Human & $\begin{array}{c}\text { Isolated human dysfunction of } \\
\text { cartilaginous endplates (CEP) } \\
\text { tissues (normal, } n=3 \text { ) and (IDD } \\
\text { patients, } n=15 \text { ) }\end{array}$ & $\begin{array}{c}\text { Normal and } \\
\text { degenerated CEP cells }\end{array}$ & $\mathrm{ER} \alpha$ & TGF- $\beta$ & $\begin{array}{l}\text { Treatment with estrogen }(0.1-1 \mu \mathrm{M}) \text { could attenuate } \\
\text { intervertebral disc degeneration by miR-221 through } \\
\text { targeting ER } \alpha \text {. }\end{array}$ & [96] \\
\hline & miR-203-3p & Human & $\begin{array}{l}\text { Nucleus pulposus samples were } \\
\text { from IDD patients }(n=27) \text { with } \\
\text { different grades (G1-3) }\end{array}$ & $\begin{array}{l}\text { Human nucleus } \\
\text { pulposus }\end{array}$ & ER $\alpha$ & - & $\begin{array}{l}\text { Suppression of miR-203-3p via upregulating ER } \alpha \\
\text { could inhibit lipopolysaccharide-induced human } \\
\text { IDD and inflammation. }\end{array}$ & [97] \\
\hline $\begin{array}{l}\text { Endometrial } \\
\text { carcinoma (EC) }\end{array}$ & miR-195 & Human & & $\begin{array}{l}\text { AN3-CA, } \\
\text { Hec1A }\end{array}$ & GPER & PI3K/AKT & $\begin{array}{l}\text { miR-195 was overexpressed in the mimics group. } \\
\text { Overexpression of miR-195 by targeting GPER could } \\
\text { inhibit EMT process in EC. }\end{array}$ & [70] \\
\hline $\mathrm{EC}$ & miR-107-5p & Human & $\begin{array}{l}\text { EC samples }(n=71), \text { normal } \\
\text { controls }(n=26)\end{array}$ & $\begin{array}{l}\text { Ishikawa, 293T } \\
\text { HEC-1B }\end{array}$ & ER $\alpha$ & - & $\begin{array}{l}\text { miR-107-5p via targeting ER } \alpha \text { could promote tumor } \\
\text { proliferation and invasion in endometrial carcinoma. }\end{array}$ & [69] \\
\hline $\begin{array}{l}\text { Pelvic Organ } \\
\text { Prolapse (POP) }\end{array}$ & miR-92 & Human & $\begin{array}{l}56 \text { POP patients and } \\
48 \text { non-POP control }\end{array}$ & - & ER $\beta 1$ & - & $\begin{array}{l}\text { miR-92 via downregulating ER } \beta 1 \text { in the cervical } \\
\text { portion of uterosacral ligaments could be involved in } \\
\text { the pathogenesis of POP. }\end{array}$ & {$[101]$} \\
\hline $\begin{array}{l}\text { Trophoblast } \\
\text { Carcinoma }\end{array}$ & miR-18a & Human & & JEG-3 & $\mathrm{ER} \alpha$ & - & $\begin{array}{l}\text { Suppression of miR-18a expression by targeting ER } \alpha \\
\text { could promote apoptosis and inhibit invasion and of } \\
\text { human trophoblast cells. }\end{array}$ & {$[103]$} \\
\hline $\begin{array}{l}\text { Hepatocellular } \\
\text { Carcinoma } \\
\text { (HCC) }\end{array}$ & $\mathrm{miR}-221$ & Human & & $\begin{array}{c}\text { HepG2, } \\
\text { MCF-7, HepG2.215 }\end{array}$ & $\mathrm{ER} \alpha$ & - & $\begin{array}{l}\text { Hepatitis B virus } \mathrm{X} \text { protein }(\mathrm{HBx}) \text { could increase the } \\
\text { expression of miR-221 and miR-221 via suppressing } \\
\mathrm{ER} \alpha \text { could promote HCC cancer cell proliferation. }\end{array}$ & [71] \\
\hline HCC & miR-21 & Human & & $\begin{array}{l}\text { HepG2, Нер3B, } \\
\text { SK-HEP-1 }\end{array}$ & $\begin{array}{l}\text { GPER, PDCD4, } \\
\text { ER } \alpha 36\end{array}$ & $\begin{array}{l}\text { PI3K/AKT, } \\
\text { EGFR, MAPK, } \\
\text { ERK1/2 }\end{array}$ & $\begin{array}{l}\text { Treatment with DHEA }(10 \mathrm{nM}) \text { via activating GPER } \\
\text { could stimulate transcription of miR-21 in HCCs. }\end{array}$ & [85] \\
\hline Osteoporosis & miR-148a & Rat & & MC3T3-E1 & $\mathrm{ER} \alpha$ & PI3K/AKT & $\begin{array}{c}\text { Downregulation of miR-148a via PI3K/AKT signaling } \\
\text { by ER } \alpha \text { could protect against } \\
\text { ovariectomy-induced osteoporosis. }\end{array}$ & {$[105]$} \\
\hline $\begin{array}{l}\text { Nasopharyngeal } \\
\text { Cancer }\end{array}$ & $\operatorname{miR}-375$ & Rat & & CNE2 & $\begin{array}{l}\mathrm{ER} \alpha, \\
\text { PTEN, } \\
\text { Bcl-2 }\end{array}$ & ERK1/2 & $\begin{array}{l}\text { Treatment with formononetin }(0.3 \mu \mathrm{M}) \text { increased } \\
\text { miR-375 levels in CNE2 cells. Low concentration of } \\
\text { formononetin through the } \\
\text { ER } \alpha / \text { miR-375/PTEN/ERK1/2/Bcl-2 pathway } \\
\text { could promote the proliferation of ER+ cells. }\end{array}$ & [53] \\
\hline Osteoarthritis & miR-203 & & $\begin{array}{c}\text { Osteoarthritis postmenopausal } \\
\text { patients }(n=34) \text {, normal controls } \\
\qquad(n=20)\end{array}$ & Human chondrocytes & $\mathrm{ER} \alpha$ & - & $\begin{array}{l}\text { miR-203 via regulating ER } \alpha \text { could enhance cartilage } \\
\text { degradation in IL- } 1 \beta \text {-stimulated chondrocytes. }\end{array}$ & [98] \\
\hline
\end{tabular}


Table 2. Cont

\begin{tabular}{|c|c|c|c|c|c|c|c|c|}
\hline Diseases & microRNA & Human/Animal & Number of Clinical Samples & Assessed Cell Line & Targets/Regulators & $\begin{array}{l}\text { Signaling } \\
\text { Pathways }\end{array}$ & Function & Ref \\
\hline Osteoarthritis & miR-203 & Rat & & - & $\mathrm{ER} \alpha$ & - & $\begin{array}{l}\text { Inhibition of miR-203 by targeting ER } \alpha \text { could } \\
\text { ameliorate osteoarthritis cartilage degradation in the } \\
\text { postmenopausal rat model. }\end{array}$ & [99] \\
\hline Osteosarcoma & miR-125a & Human & & $\begin{array}{l}\text { U2OS, } \\
\text { MG63 }\end{array}$ & ERR $\alpha$ & - & $\begin{array}{l}\text { Treatment with curcumin }(20 \mathrm{mM}) \text { by suppressing } \\
\text { ERR } \alpha \text { through upregulation of miR-125a could } \\
\text { promote osteosarcoma cell death. }\end{array}$ & [54] \\
\hline $\begin{array}{l}\text { Cerebral I/R } \\
\text { Injury }\end{array}$ & miR-181a & Mouse & & Primary astrocyte & $\mathrm{ER} \alpha$ & - & $\begin{array}{l}\text { Inhibition of miR-181a by targeting ER } \alpha \text { could } \\
\text { enhance E2 (20 nM)-mediated stroke protection } \\
\text { in females. }\end{array}$ & {$[106]$} \\
\hline $\begin{array}{c}\text { Colorectal } \\
\text { Cancer (CRC) }\end{array}$ & miR-129 & Human & $\begin{array}{l}18 \text { pairs of CRC tissue samples } \\
\text { and adjacent normal tissues }\end{array}$ & HCT116 & $\begin{array}{l}\text { ER } \beta, \text { PCNA, } \\
\text { Caspase-3 }\end{array}$ & - & $\begin{array}{l}\text { The high expression level of miR-129 by targeting } \\
\text { ER } \beta \text { could contribute to aberrant CRC cell } \\
\text { proliferation and migration. }\end{array}$ & [62] \\
\hline $\begin{array}{l}\text { Coronary Heart } \\
\text { Disease (CHD) }\end{array}$ & miR-18a & Human & $\begin{array}{l}\text { A total of } 120 \text { blood samples } \\
\text { collected from CHD patients and } \\
\text { normal controls }\end{array}$ & HUVECs & ER & PI3K/Akt/mTOR & $\begin{array}{l}\text { miR-18a via the } \mathrm{ER} / \mathrm{PI} 3 \mathrm{~K} / \mathrm{Akt} / \mathrm{mTOR} \text { axis could } \\
\text { regulate } \mathrm{CHD} \text { development. }\end{array}$ & {$[104]$} \\
\hline Bladder Cancer & miR-92a & $\begin{array}{c}\text { Mouse, } \\
\text { TCGA database }\end{array}$ & & $\begin{array}{l}\text { UMUC3, } \\
\text { J82 }\end{array}$ & DAB2IP & $\mathrm{ER} \beta$ & $\begin{array}{l}\mathrm{ER} \beta \text { via alteration of miR-92a/DAB2IP signals could } \\
\text { promote bladder cancer growth and invasion. }\end{array}$ & [86] \\
\hline - & $\begin{array}{c}\text { miR-30b-5p, } \\
\text { miR-487a-5p, } \\
\text { miR-4710, } \\
\text { miR-501-3p }\end{array}$ & Human & & HUVEC & $\begin{array}{l}\text { ER } \alpha, \text { ER } \beta, \\
\text { GPER }\end{array}$ & - & $\begin{array}{l}\text { Treatment with E2 }(1 \mathrm{nmol} / \mathrm{L}) \text { increased the } \\
\text { expression of mentioned-microRNAs in HUVEC cells. } \\
\text { In human endothelial cells, expressed miRNA } \\
\text { pathways linked to E2 through ER demonstrate that } \\
\text { estrogen can modulate endothelial function. }\end{array}$ & [82] \\
\hline - & miR-26b-3p & Human & & hUC-MSC & ESR1, CCND1 & - & $\begin{array}{c}\text { miR-26b-3p by targeting ESR1 could regulate the } \\
\text { proliferation of human umbilical cord-derived } \\
\text { mesenchymal stem cells. }\end{array}$ & {$[107]$} \\
\hline
\end{tabular}


Table 3. List of downregulated ER-associated miRNAs in disorders.

\begin{tabular}{|c|c|c|c|c|c|c|c|c|}
\hline Diseases & microRNA & Human/Animal & Number of Clinical Samples & Assessed Cell Line & Targets/Regulators & $\begin{array}{l}\text { Signaling } \\
\text { Pathways }\end{array}$ & Function & Ref \\
\hline $\begin{array}{l}\text { Breast Cancer } \\
\text { (BCa), Prostate } \\
\text { Cancer (PC) }\end{array}$ & miR-135b & Human & $\begin{array}{l}\text { MicMa cohort (101 primary } \\
\text { breast carcinoma samples), } \\
\text { METABRIC database, } \\
\text { PCa samples }(n=47)\end{array}$ & $\begin{array}{l}\text { HMEC, DU-145, PNT2, } \\
\text { MCF-7, PC-3 LNCap, } \\
\text { 22Rv1, BT-474, JIMT-1, } \\
\text { KPL-4, VCaP }\end{array}$ & $\begin{array}{l}\text { ER } \alpha \\
\text { HIF1AN }\end{array}$ & $\mathrm{HIF} 1 \alpha$ & $\begin{array}{l}\text { miR-135b expression is downregulated in the ER } \alpha+ \\
\text { tumors relative to the } E R \alpha \text { - tumors. miR-135b could } \\
\text { affect breast and prostate cancer cell growth by } \\
\text { regulating ER } \alpha, A R \text { and HIF1AN and regulate } \\
\text { proliferation in } E R \alpha+B C a \text { and AR+ PCa cells. }\end{array}$ & [66] \\
\hline \multirow[t]{7}{*}{$\mathrm{BCa}$} & miR-320a & Human cell line & & $\begin{array}{l}\text { T47D, } \\
\text { MCF-7 }\end{array}$ & $\begin{array}{l}\text { ERR } \gamma, \\
\text { ARPP-19, } \\
\text { c-Myc, } \\
\text { Cyclin D1 }\end{array}$ & - & $\begin{array}{l}\text { Knockdown of miR-320a by targeting ARPP-19 and } \\
\text { ERR } \gamma \text { could reduce the sensitivity of tamoxifen in } \\
\text { ER+ breast cancer cell lines. }\end{array}$ & [75] \\
\hline & miR-338-3p & Human cell line & & $\begin{array}{l}\text { SkBr3, } \\
\text { CAFs }\end{array}$ & GPER & - & $\begin{array}{l}\text { Treatment with E2 (100 nM) decreased the expression } \\
\text { of miR-338-3p in SkBr3 cancer cells and } \\
\text { cancer-associated fibroblasts (CAFs). In the } \\
\text { regulation of miR-338-3p by E2, the GPER is involved. }\end{array}$ & [87] \\
\hline & miR-451 & Human cell line & & $\begin{array}{c}\text { MCF-7, } \\
\text { MCF-7/Dox }\end{array}$ & $\begin{array}{c}\text { ER, ABCB1, } \\
\text { Caspase-3, Pgp }\end{array}$ & - & $\begin{array}{l}\text { Resistance to doxorubicin is correlated with } \\
\text { dysregulation of the miR-451/ER axis in BCa cell line. }\end{array}$ & {$[108]$} \\
\hline & miR-451a & Human cell line & & $\begin{array}{l}\text { MCF-7, } \\
\text { LCC2 }\end{array}$ & $\begin{array}{c}\mathrm{ER} \alpha \\
14-3-3 \zeta\end{array}$ & $\begin{array}{l}\text { AKT, } \\
\text { mTOR }\end{array}$ & $\begin{array}{l}\text { The expression of miR-451a is decreased in LCC2 } \\
\text { cells compared to MCF-7 cells. Treatment with } \\
\text { tamoxifen (TAM) could downregulate ER } \alpha \\
\text { expression and upregulate } 14-3-3 \zeta \text { expression. Hence, } \\
\text { overexpression of miR-451 via activating ER } \alpha \text { and } \\
\text { inactivating } 14-3-3 \zeta \text { could enhance the sensitivity of } \\
\text { breast cancer cells to TAM. }\end{array}$ & [76] \\
\hline & miR-497 & Human & $\begin{array}{l}\mathrm{ER} \alpha+\mathrm{BCa}(\mathrm{EPBC}, n=30 \text { tissues), } \\
\mathrm{ER} \alpha-\mathrm{Bca}(\mathrm{ENBC}, n=30 \text { tissues) }\end{array}$ & $\begin{array}{c}\text { MCF-7, T47D, } \\
\text { MDA-MB-231, SKBR3 }\end{array}$ & $\begin{array}{l}\text { ERR } \alpha, M I F, \\
\text { MMP9 }\end{array}$ & & $\begin{array}{l}\text { The expression of miR- } 497 \text { is reduced in ENBC } \\
\text { tissues. The downregulation of miR-497 by targeting } \\
\text { ERR } \alpha \text { could contribute to proliferation, migration, } \\
\text { and invasion of ER } \alpha-\text { BCa cells. }\end{array}$ & [67] \\
\hline & miR-124 & Human & $\begin{array}{l}46 \text { pairs of BCa samples and } \\
\text { adjacent normal tissues), } \\
\text { ER } \alpha-(n=17) \\
\text { ER } \alpha+(n=29)\end{array}$ & $\begin{array}{l}\text { MCF-7, } \\
\text { MDA-MB-231 }\end{array}$ & AKT2 & ER & $\begin{array}{l}\text { Treatment with } 17 \beta \text {-estradiol }(\mathrm{E} 2,10 \mathrm{nM}) \text { decreased } \\
\text { miR-124 levels in MSF-7 cells through ER. However, } \\
\text { overexpression of miR-124 by targeting AKT2 } \\
\text { suppressed tumor growth and angiogenesis in MCF7 } \\
\text { cells. Therefore, the ER } \alpha / \text { miR-124/AKT2 axis is } \\
\text { involved in BCa development. }\end{array}$ & [80] \\
\hline & miR-27a & Human cell line & & $\begin{array}{l}\text { MCF-7, } \\
\text { T47D }\end{array}$ & $\mathrm{ER} \alpha$ & - & $\begin{array}{c}\text { In tamoxifen }(20 \mu \mathrm{m}) \text {-resistant cells, the expression of } \\
\text { ER } \alpha \text { and miR-27a decreased. miR-27a based on a } \\
\text { positive feedback loop with ER } \alpha \text { could sensitize } \\
\text { luminal A BCa cells to selective estrogen receptor } \\
\text { modulators (SERMs) treatments }\end{array}$ & [77] \\
\hline
\end{tabular}


Table 3. Cont

\begin{tabular}{|c|c|c|c|c|c|c|c|c|}
\hline Diseases & microRNA & Human/Animal & Number of Clinical Samples & Assessed Cell Line & Targets/Regulators & $\begin{array}{l}\text { Signaling } \\
\text { Pathways }\end{array}$ & Function & Ref \\
\hline & miR-203 & Human & $\begin{array}{l}22 \text { pairs of BCa tissue samples } \\
\text { and adjacent normal tissues }\end{array}$ & MCF-7 & $\mathrm{ER} \alpha$ & - & $\begin{array}{c}\text { Treatment with E2 }(10 \mathrm{mM}) \text { decreased miR-203 levels } \\
\text { in MCF-7 cells. miR-203 via directly suppressing ER } \alpha \\
\text { could inhibit the viability, migration, and invasion of } \\
\text { estrogen-dependent } \\
\text { BCa cells. }\end{array}$ & {$[68]$} \\
\hline & miR-148a & Human cell line & & $\begin{array}{l}\text { MCF-7, } \\
293 \mathrm{~T}\end{array}$ & $\mathrm{ER} \alpha$ & - & $\begin{array}{l}\text { Overexpression of miR-148a via inhibiting ER } \alpha \text { could } \\
\text { suppress the E2 }(1 \mathrm{mM}) \text {-induced viability and } \\
\text { migration of ER } \alpha+B C \text { Ca cells. }\end{array}$ & [63] \\
\hline & miR-1271 & $\begin{array}{l}\text { Mouse, } \\
\text { TCGA database }\end{array}$ & & $\begin{array}{l}\text { MCF-7, T47D, } \\
\text { BT474, BT549, } \\
\text { MDA-MB-468, } \\
\text { MDA-MB-231 }\end{array}$ & SNAI2 & TGF- $\beta$ & $\begin{array}{c}\text { The ER } \alpha \text {-miR-1271-SNAI2 feedback loop is involved } \\
\text { in the regulation of TGF- } \beta \text { signaling during BCa } \\
\text { progression and development. }\end{array}$ & {$[60]$} \\
\hline & miR-142-3p & Human & $\begin{array}{l}20 \text { pairs of primary BCa and } \\
\text { adjacent normal breast tissues }\end{array}$ & $\begin{array}{l}\text { MDA-MB-231, MCF-7, } \\
\text { 293T }\end{array}$ & ESR1 & - & $\begin{array}{l}\text { miR-142-3p via inhibiting estrogen ESR1 could act as } \\
\text { a tumor suppressor in ER+ BCa. }\end{array}$ & {$[65]$} \\
\hline & miR-22 & Human & $\begin{array}{l}50 \text { pairs of primary } \mathrm{BCa} \text { and } \\
\text { adjacent normal breast tissues }\end{array}$ & $\begin{array}{c}\text { MDA-MB-231, MCF-7, } \\
\text { T47D, } \\
\text { SKBR-3, } \\
\text { HBL-100 }\end{array}$ & $\mathrm{ER} \alpha, \mathrm{NK} 1 \mathrm{R}-\mathrm{Tr}$ & ERK $1 / 2$ & $\begin{array}{l}\text { miR-22 via targeting } E R \alpha \text { and NK1R-Tr could inhibit } \\
\text { proliferation, invasion, and metastasis of } B C a \text { cells. }\end{array}$ & {$[64]$} \\
\hline & miR-1271 & $\begin{array}{l}\text { Mouse and } \\
\text { human }\end{array}$ & $\begin{array}{l}\text { non-responding tumor tissues ( } n \\
=30 \text { ) and responding tumor } \\
\quad \text { tissues }(n=40)\end{array}$ & $\begin{array}{c}\text { MCF-7, BT474, BT483, } \\
\text { HCC1007, HCC1569, } \\
\text { HCC1187, } \\
\text { MDA-MB-231, } \\
\text { MDA-MB-361, } \\
\text { MDA-MB-415 }\end{array}$ & $\mathrm{ER} \alpha, \mathrm{DDIT} 3$ & MAPK & $\begin{array}{c}\text { miR-1271 was downregulated in letrozole-resistant } \\
\text { BCa tissues/cells. miR-1271 by inhibiting ER } \alpha \text { could } \\
\text { alter letrozole resistance in BCa. }\end{array}$ & [79] \\
\hline & miR-145 & Human cell line & - & MCF-7, MDA-MB-231 & $\begin{array}{c}\text { ER } \beta, \text { MMP2, } \\
\text { MMP7, MMP9, } \\
\text { ECM, syndecan-1 }\end{array}$ & ERK1/2 & $\begin{array}{l}\text { In an estrogen-free medium, the expression of } \\
\text { miR-145 was decreased in MCF-7 cells. ER } \beta \text { is as an } \\
\text { epigenetic mediator of miR-145 to target EMT and } \\
\text { ECM in mammary cancer. }\end{array}$ & {$[88]$} \\
\hline & miR-125a-3p & Human & $\begin{array}{l}37 \text { cancerous tissues paired with } \\
\text { noncancerous samples }\end{array}$ & $\begin{array}{c}\text { MCF-7, } \\
\text { MDA-MB-435, } \\
\text { MDA-MB-231 }\end{array}$ & $\mathrm{ER} \alpha, \mathrm{CDK} 3$ & - & $\begin{array}{l}\text { miR-125a-3p via inhibiting ER } \alpha \text { transactivation and } \\
\text { targeting CDK3 could override tamoxifen resistance } \\
\text { in ER+ breast cancer. }\end{array}$ & {$[78]$} \\
\hline $\begin{array}{l}\text { Thyroid Cancer } \\
\text { (TC) }\end{array}$ & miR-1280 & Human & $\begin{array}{l}12 \text { pairs of follicular thyroid } \\
\text { cancer and adjacent } \\
\text { non-neoplastic tissues }\end{array}$ & $\begin{array}{l}\text { FTC133, TT, } \\
\text { Nthy-ori 3-1 }\end{array}$ & $\mathrm{ER} \alpha$ & ERK & $\begin{array}{l}\text { Overexpression of miR-1280 by inhibiting ER } \alpha \text { could } \\
\text { promote cell proliferation and invasion in TC cells. }\end{array}$ & {$[72]$} \\
\hline $\begin{array}{l}\text { Ovarian Cancer } \\
\text { (OC) }\end{array}$ & miR-486-5p & Human & $\begin{array}{l}\text { Ovarian serous adenocarcinoma } \\
(n=6) \text { and normal ovary }(n=8)\end{array}$ & $\begin{array}{l}\text { SKOV3, } \\
\text { HO8910-pm }\end{array}$ & OLFM4 & ER & $\begin{array}{l}\text { Treatment with 17 } \beta \text {-estradiol (E2) decreased } \\
\text { miR-486-5p levels in SKOV3 cells. However, } \\
\text { ER/miR-486-5p/OLFM4 axis could be involved in the } \\
\text { development and progression of ovarian cancer. }\end{array}$ & {$[74]$} \\
\hline
\end{tabular}


Table 3. Cont

\begin{tabular}{|c|c|c|c|c|c|c|c|c|}
\hline Diseases & microRNA & Human/Animal & Number of Clinical Samples & Assessed Cell Line & Targets/Regulators & $\begin{array}{l}\text { Signaling } \\
\text { Pathways }\end{array}$ & Function & Ref \\
\hline $\begin{array}{l}\text { Hepatocellular } \\
\text { Carcinoma } \\
\text { (HCC) }\end{array}$ & miR-141-3p & $\begin{array}{l}\text { Mouse and } \\
\text { human }\end{array}$ & $\begin{array}{l}24 \text { pairs of HCC and adjacent } \\
\text { normal liver tissues }\end{array}$ & $\begin{array}{l}\text { SK-HEP-1, } \\
\text { 293T, HA22T }\end{array}$ & $\begin{array}{l}\text { ER } \alpha, \\
\text { circRNA-SMG1.72, } \\
\text { gelsolin }\end{array}$ & - & $\begin{array}{l}\text { ER } \alpha \text { via altering the } \\
\text { ER } \alpha / \text { circRNA-SMG1.72/miR-141-3p/GSN axis could } \\
\text { suppress HCC cell invasion. }\end{array}$ & [109] \\
\hline $\begin{array}{l}\text { Prostate Cancer } \\
\text { (PC) }\end{array}$ & miR-135a & Human cell line & - & $\begin{array}{l}\text { MDA-MB-231, } \\
\text { PC3, LNCaP }\end{array}$ & ERR $\alpha$ & - & $\begin{array}{l}\text { Overexpression of miR-135a via suppressing ERR } \alpha \\
\text { could inhibit the invasion of prostatic cancer cells. }\end{array}$ & [110] \\
\hline Osteoporosis & miR-210-3p & Human cell line & - & rBMSCs & - & Wnt & $\begin{array}{l}\text { In ER } \alpha \text {-deficient model, miR-210-3p through Wnt } \\
\text { signaling could promote adipogenic differentiation } \\
\text { and inhibit osteogenic differentiation of rBMSCs. }\end{array}$ & [111] \\
\hline $\begin{array}{l}\text { Colorectal } \\
\text { Cancer (CRC) }\end{array}$ & miR-95 & Human cell line & & SW480, LoVo, HeLa & ER $\beta$ & $\begin{array}{l}\text { IGF-1R, } \\
\text { PI3K/Akt }\end{array}$ & $\begin{array}{l}\text { Calycosin }(80 \mu \mathrm{M}) \text { could inhibit human CRC cell } \\
\text { proliferation by targeting miR-95 through ER } \beta \text {. }\end{array}$ & [55] \\
\hline CRC & miR-205 & Human & $\begin{array}{l}\text { RNA-seq data (233 primary } \\
\text { colon cancer specimens and } 21 \\
\text { adjacent normal tissues) }\end{array}$ & $\begin{array}{l}\text { SW480, HT29, HCT116, } \\
\text { SW403, SW620, 293T }\end{array}$ & PROX1 & ER $\beta$ & $\begin{array}{l}\text { ER } \beta \text { upregulates miR-205 and that miR-205 by } \\
\text { targeting and repressing PROX1 could reduce the } \\
\text { proliferative and metastatic potential of the CRC cells. }\end{array}$ & [89] \\
\hline - & miR-320a & Human cell line & - & HTR.8/Svneo, HUVECs & $\begin{array}{l}\text { ERR } \gamma, \text { VEGF, } \\
\text { Ang-1, HCG, } \\
\text { HSD3B1 }\end{array}$ & - & $\begin{array}{l}\text { Overexpression of miR-320a by inhibiting ERR } \gamma \\
\text { could downregulate the expression of } \\
\text { trophoblast-associated markers and } \\
\text { angiogenesis-related factors in trophoblasts and } \\
\text { endothelial cells. }\end{array}$ & [95] \\
\hline- & miR-26b-3p & Human cell line & - & $\begin{array}{l}\text { MC3T3-E1, } \\
\text { 293T }\end{array}$ & $\mathrm{ER} \alpha$ & - & $\begin{array}{l}\text { miR-26b-3p via targeting ER } \alpha \text { could regulate } \\
\text { osteoblast differentiations. }\end{array}$ & [100] \\
\hline - & $\begin{array}{l}\mathrm{miR}-378 \mathrm{~h}, \\
\mathrm{miR}-1244\end{array}$ & Human cell line & - & HUVEC & $\begin{array}{l}\text { ER } \alpha, E R \beta, \\
\text { GPER }\end{array}$ & - & $\begin{array}{l}\text { Treatment with E2 }(1 \mathrm{nmol} / \mathrm{L}) \text { decreased the } \\
\text { expression of mentioned-microRNAs in HUVEC cells. } \\
\text { In human endothelial cells, expressed miRNA } \\
\text { pathways linked to E2 through ER demonstrate that } \\
\text { estrogen can modulate endothelial function. }\end{array}$ & [82] \\
\hline - & miR-221 & Rat & - & - & $\mathrm{ER} \alpha$ & $\begin{array}{c}\text { ERK1/2, } \\
\text { NF-kB, AKT }\end{array}$ & $\begin{array}{l}\text { Treatment with E2 }(40 \mu \mathrm{g} / \mathrm{kg}) \text { by suppressing hepatic } \\
\text { iNOS through the activation of the ER } \alpha \text { could } \\
\text { inhibition of ERK1/2-mir-221 axis. }\end{array}$ & [112] \\
\hline $\begin{array}{c}\text { Idiopathic } \\
\text { Pulmonary } \\
\text { Fibrosis (IPF) }\end{array}$ & let-7a/d & $\begin{array}{l}\text { Mouse and } \\
\text { human }\end{array}$ & $\begin{array}{l}\text { lung tissue of IPF patients }(n=8) \\
\text { and normal controls }(n=6)\end{array}$ & Myofibroblast & $\mathrm{ER} \alpha, \mathrm{ER} \beta$ & $\begin{array}{l}\text { TGF- } \beta, \text { AKT, } \\
\text { SMAD }\end{array}$ & $\begin{array}{l}\text { let-7/ER axis is involved in the pathogenesis of } \\
\text { predominant pulmonary fibrosis. }\end{array}$ & [113] \\
\hline
\end{tabular}




\section{CircRNAs and ER Functions in Cancer}

CircRNAs comprise a group of non-coding RNAs that are particularly stable and also have been associated with ER function. Similar to lncRNAs, they regulate the expression of several genes that are involved in diverse physiological and pathological processes. A possible mechanism for the participation of circRNAs in carcinogenesis is that they might serve as miRNA sponges [114]. Recently, investigators have assessed the circRNA signature in breast cancer and nearby normal tissues. The authors detected the differential expression of 1155 circRNAs between these two sets of samples. hsa_circ_103110, hsa_circ_104689 and hsa_circ_104821 were among the upregulated circRNAs, while expressions of hsa_circ_006054, hsa_circ_100219 and hsa_circ_406697 were decreased in breast cancer tissues [115]. Using a bioinformatics approach to recognize expressed circRNAs in breast cancer cell lines and clinical samples, greater quantities of circRNAs were detected in adjacent normal tissues of ER+ breast cancer samples compared to tumor samples [116]. Furthermore, an inverse correlation was observed between the quantities of circRNAs in adjacent normal tissues of ER+ samples and the risk-of-relapse proliferation score for proliferating genes. The latter finding implies that circRNA levels may be indicative of cell proliferation in breast cancer [116]. An examination of highly expressed circRNA isoforms spliced from ESR1 that were differentially expressed in ER+ breast cancer tissues compared with other malignancies and normal breast tissue were found to be resistant to destruction by ribonuclease $\mathrm{R}$, while the corresponding linear mRNA was prone to degradation by this enzyme. Based on the stability of circRNAs in the plasma, these circRNAs were proposed as putative biomarkers for the early non-invasive diagnosis of cancer [117]. In a recent study, the expression signature of circRNA was compared between ER-positive breast cancer tissues and their nearby non-tumor tissues. In total, more than 3000 differentially expressed circRNAs were identified between these two sets of samples. These circRNAs were enriched cancer-associated pathways. In addition, hsa_circ_0087378 has been verified to be downregulated in ER+ breast cancer samples and the hsa_circ_0087378-miR-1260b-SFRP1 axis has been recognized as an important regulatory axis in this type of cancer [118]. Finally, in ER $\alpha$-associated circ-SMG1, the 72/miR-141-3p/gelsolin axis has been proposed as a strategy for the inhibition of HCC cell invasion [109]. Taken together, cicRNAs are potential regulators of ER signaling and their dysregulation participates in the pathogenesis of ER-related cancers, especially breast cancer. However, functional studies in this field are scarce.

\section{Discussion}

Several miRNAs and lncRNAs participate in the regulation of ER functions. Figure 2 depicts the mechanism of participation of a number of these transcripts in the regulation of ER in breast cancer. ER-associated ncRNAs regulate cancer initiation, progression and metastasis. Their role in the modulation of metastatic potential of cancer cells has been highlighted through the observed association between the expression of some ncRNAs such as miR-10b, miR-145 and miR-497 and the expression of MMP proteins. In addition, miRNAs might have diverse targets that modulate various steps in the carcinogenesis process. For instance, the ER-associated miRNA miR-21 has been shown to target several genes, namely TIMP3, PDCD4, PTEN, TPM1 and RECK, which participate in numerous aspects of cancer progression including invasion, angiogenesis and metastasis [119]. The IncRNA DSCAM-AS1, which is expressed in ER $\alpha+$ breast cancer tissues, is absent from pre-neoplastic samples [36], indicating a role for this lncRNA in the primary steps of breast carcinogenesis.

Understanding the molecular mechanisms of such contributions has practical significance in the management of several human disorders such as breast cancer. The observed endocrine resistance in a proportion of patients with this kind of cancer can be at least partly explained by the dysregulation in the expression of miRNAs/lncRNAs. Resistance to endocrine therapies is complicated process that involves epigenetic alterations in the ESR1 gene, alternative splicing events, post-translational alterations and altered recruitment of co-regulators of ER; it also affects the tumor milieu and several other mechanisms [120]. Almost all aspects of this complex process can be modulated by non-coding RNAs. Numerous miRNAs directly bind with the ESR1 gene to suppress its expression and induce 
resistance to estrogen/ER $\alpha$-targeted therapeutic modalities in cancers [91]. Moreover, a number of herbal compounds have been shown to affect the functional links between ERs and non-coding RNAs, thus exerting anti-proliferative or proliferative effects on cancer cells.

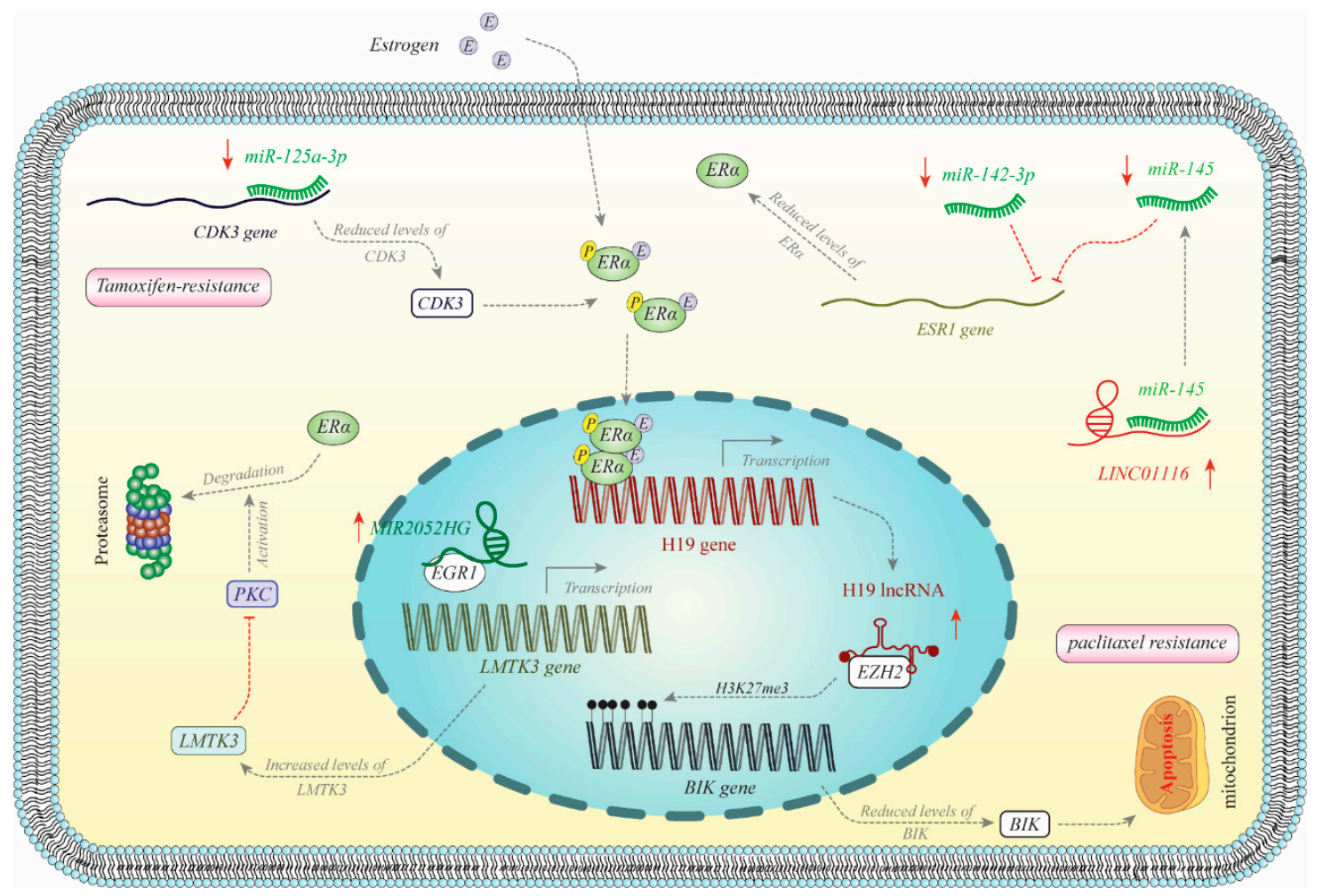

Figure 2. Schematic diagram illustrating mechanisms of noncoding RNA regulation of ER in breast cancer. Expression of miR-125a is increased in tamoxifen-resistant breast cancer cells. miR-125a binds to the 3' UTR of CDK3 to inhibit its expression. CDK3 phosphorylates ER and increases its activity [78]. MIR2052HG is over-expressed in ER $\alpha$-positive breast cancer cells. MIR2052HG facilitates binding of EGR1 with the promoter of the LMTK3 gene to enhance its expression. LMTK3 inhibits PKC and reduces ER degradation [45]. H19 is one the downstream targets of ER $\alpha$. H19 is increased in ER $\alpha$-positive breast cancer cells. H19 recruits EZH2 and enhances H3K27me3 of BIK promoter to reduce its expression, inhibit apoptosis and induce resistance to therapeutic options [30]. LINC01116 is increased in breast cancer tissues and acts as a sponge for miR-145, which binds with the 3' UTR of ESR1 to inhibit its expression. Thus, over-expression of LINC01116 enhances ER levels [29]. miR-142-3p is downregulated in ER-positive breast cancer cells. This miRNA binds with 3' UTR of ESR1 to inhibit its expression [65].

Consistent with the widespread expression pattern of some types of ERs, the dysregulation of ER-associated lncRNAs/miRNAs has been involved in the pathogenesis of several disorders in almost all organ systems such as the reproductive, musculoskeletal, cardiac and gastrointestinal, endocrine systems, among others. The contribution of ER is not confined to the malignant status of these tissues. Myasthenia gravis, IDD, POP and preeclampsia represent a few examples of the significance of the functional link between non-coding RNAs and ERs. Based on the presence of complex interactions between miRNAs and ERs, and the competing effects of ER $\alpha$ and ER $\beta$ in some situations, a comprehensive assessment of miRNA signatures is needed to elaborate the underlying mechanisms of ER-associated pathologies. LncRNAs and miRNAs represent molecular biomarkers for some of these conditions. The therapeutic potential of these transcripts has also been assessed in some instances. For instance, the results of an animal study revealed that miR-181a silencing can inhibit transient focal cerebral ischemia by targeting ER $\alpha$ in astrocytes [106]. Moreover, an in vitro study showed the effects of the transfection of let-7 mimicked in human myofibroblasts on decreasing ER $\alpha$ expression 
and the related fibrotic pathways, thus highlighting this strategy for the treatment of idiopathic lung fibrosis [113]. Further assessments of the effects of the manipulation of non-coding RNAs expression in animal models would provide novel therapeutic strategies for ER-associated conditions.

\section{Therapeutic Perspectives and Future Directions}

LncRNAs and miRNAs are involved in several aspects of ER functions in both up- and downstream signaling pathways. Based on the crucial roles of ER-related signaling pathways in diverse human disorders, particularly cancers, the modulation of the expression of these transcripts can interfere with the progression of ER-related disorders or therapeutic responses to drugs that interfere with ER signaling. The most valuable results have been obtained from investigations in breast cancer, where the modulation of the expression of non-coding RNAs altered the response of cancer cells not only to tamoxifen, but also to herbal anti-cancer drugs. However, this field has been less explored for other malignant and non-malignant conditions that are associated with ER signaling. Thus, future in vitro and in vivo studies should assess the efficacy of non-coding RNA-mediated therapies in these conditions. Moreover, the interactive network between circRNAs and other non-coding RNAs, particularly miRNAs, is another research field which should be explored in future studies. This complex network might also alter the disease course or response to endocrine therapies. Considering the role of ER signaling in diverse aspects of the carcinogenesis process including both pathogenic events in cancer cells and the modulation of the tumor microenvironment, novel ER-targeted therapies are expected to effectively alter the course of cancer. Future investigations should focus on the design of the next generation of these molecules, considering their differential effects on diverse cell types, which are present in the tumor niche.

Author Contributions: Conceptualization, M.T. and H.S.; methodology, M.T., H.S.; validation, M.E.D., S.G.-F.; writing-original draft preparation, S.G.-F.; writing—review and editing, M.E.D., S.G.-F.; project administration, M.E.D., S.G.-F. All authors have read and agreed to the published version of the manuscript.

Funding: This research received no external funding.

Conflicts of Interest: The authors declare no conflict of interest.

\section{References}

1. Matthews, J.; Gustafsson, J.-Å. Estrogen signaling: A subtle balance between ER $\alpha$ and ER $\beta$. Mol. Interv. 2003, 3, 281. [CrossRef] [PubMed]

2. Levin, E.R. Integration of the extranuclear and nuclear actions of estrogen. Mol Endocrinol. 2005, 19, 1951-1959. [CrossRef] [PubMed]

3. Bondesson, M.; Hao, R.; Lin, C.-Y.; Williams, C.; Gustafsson, J.-Å. Estrogen receptor signaling during vertebrate development. Biochim. Biophys. Acta. 2015, 1849, 142-151. [CrossRef]

4. Curtis Hewitt, S.; Couse, J.F.; Korach, K.S. Estrogen receptor transcription and transactivation: Estrogen receptor knockout mice: What their phenotypes reveal about mechanisms of estrogen action. Breast Cancer Res. 2000, 2, 345-352. [CrossRef] [PubMed]

5. Curtis, S.W.; Washburn, T.; Sewall, C.; DiAugustine, R.; Lindzey, J.; Couse, J.F.; Korach, K.S. Physiological coupling of growth factor and steroid receptor signaling pathways: Estrogen receptor knockout mice lack estrogen-like response to epidermal growth factor. Proc. Natl. Acad. Sci. USA 1996, 93, 12626-12630. [CrossRef] [PubMed]

6. Ignar-Trowbridge, D.M.; Pimentel, M.; Parker, M.; McLachlan, J.; Korach, K. Peptide growth factor cross-talk with the estrogen receptor requires the A/B domain and occurs independently of protein kinase $\mathrm{C}$ or estradiol. Endocrinology 1996, 137, 1735-1744. [CrossRef] [PubMed]

7. Zhao, C.; Matthews, J.; Tujague, M.; Wan, J.; Ström, A.; Toresson, G.; Eric, W.-F.; Cheng, G.; Gustafsson, J.A.; Dahlman-Wright, K. Estrogen receptor $\beta 2$ negatively regulates the transactivation of estrogen receptor $\alpha$ in human breast cancer cells. Cancer Res. 2007, 67, 3955-3962. [CrossRef]

8. Weihua, Z.; Saji, S.; Mäkinen, S.; Cheng, G.; Jensen, E.V.; Warner, M.; Gustafsson, J.A. Estrogen receptor (ER) beta, a modulator of ERalpha in the uterus. Proc. Natl. Acad. Sci. USA 2000, 97, 5936-5941. [CrossRef] 
9. Stettner, M.; Kaulfuß, S.; Burfeind, P.; Schweyer, S.; Strauss, A.; Ringert, R.-H.; Thelen, P. The relevance of estrogen receptor- $\beta$ expression to the antiproliferative effects observed with histone deacetylase inhibitors and phytoestrogens in prostate cancer treatment. Mol. Cancer Ther. 2007, 6, 2626-2633. [CrossRef]

10. Toran-Allerand, C.D.; Guan, X.; MacLusky, N.J.; Horvath, T.L.; Diano, S.; Singh, M.; Sander Connolly, E., Jr.; Nethrapalli, I.S.; Tinnikov, A.A. ER-X: A novel, plasma membrane-associated, putative estrogen receptor that is regulated during development and after ischemic brain injury. J. Neurosci. 2002, 22, 8391-8401. [CrossRef]

11. Srivastava, D.; Evans, P. G-protein oestrogen receptor 1: Trials and tribulations of a membrane oestrogen receptor. J. Neuroendocrinol. 2013, 25, 1219-1230. [CrossRef] [PubMed]

12. Gustafsson, K.L.; Farman, H.; Henning, P.; Lionikaite, V.; Movérare-Skrtic, S.; Wu, J.; Ryberg, H.; Koskela, A.; Gustafsson, J.; Tuukkanen, J.; et al. The role of membrane ER $\alpha$ signaling in bone and other major estrogen responsive tissues. Sci. Rep. 2016, 6, 29473. [CrossRef] [PubMed]

13. Fernandes, J.C.R.; Acuña, S.M.; Aoki, J.I.; Floeter-Winter, L.M.; Muxel, S.M. Long Non-Coding RNAs in the Regulation of Gene Expression: Physiology and Disease. Noncoding RNA 2019, 5, 17. [CrossRef] [PubMed]

14. Catalanotto, C.; Cogoni, C.; Zardo, G. MicroRNA in Control of Gene Expression: An Overview of Nuclear Functions. Int. J. Mol. Sci. 2016, 17, 1712. [CrossRef]

15. Barrett, S.P.; Salzman, J. Circular RNAs: Analysis, expression and potential functions. Development 2016, 143, 1838-1847. [CrossRef]

16. Malley, B.W. Little molecules with big goals. Science 2006, 313, 1749. [CrossRef]

17. Qin, L.; Liao, L.; Redmond, A.; Young, L.; Yuan, Y.; Chen, H.; O’Malley, B.W.; Xu, J. The AIB1 oncogene promotes breast cancer metastasis by activation of PEA3-mediated matrix metalloproteinase 2 (MMP2) and MMP9 expression. Mol. Cell. Biol. 2008, 28, 5937-5950. [CrossRef]

18. Qin, L.; Liu, Z.; Chen, H.; Xu, J. The steroid receptor coactivator-1 regulates twist expression and promotes breast cancer metastasis. Cancer Res. 2009, 69, 3819-3827. [CrossRef]

19. Sun, Y.; Wang, Y.; Fan, C.; Gao, P.; Wang, X.; Wei, G.; Wei, J. Estrogen promotes stemness and invasiveness of ER-positive breast cancer cells through Gli1 activation. Mol. Cancer 2014, 13, 137. [CrossRef]

20. Wang, Q.; Jiang, J.; Ying, G.; Xie, X.Q.; Zhang, X.; Xu, W.; Zhang, X.; Song, E.; Bu, H.; Ping, Y.F.; et al. Tamoxifen enhances stemness and promotes metastasis of ER $\alpha 36(+)$ breast cancer by upregulating ALDH1A1 in cancer cells. Cell Res. 2018, 28, 336-358. [CrossRef]

21. Amin, A.; Karpowicz, P.A.; Carey, T.E.; Arbiser, J.; Nahta, R.; Chen, Z.G.; Dong, J.T.; Kucuk, O.; Khan, G.N.; Huang, G.S.; et al. Evasion of anti-growth signaling: A key step in tumorigenesis and potential target for treatment and prophylaxis by natural compounds. Semin. Cancer Biol. 2015, 35, S55-s77. [CrossRef]

22. Lewis-Wambi, J.S.; Jordan, V.C. Estrogen regulation of apoptosis: How can one hormone stimulate and inhibit? Breast Cancer Res. 2009, 11, 206. [CrossRef]

23. Rothenberger, N.J.; Somasundaram, A.; Stabile, L.P. The Role of the Estrogen Pathway in the Tumor Microenvironment. Int. J. Mol. Sci. 2018, 19, 611. [CrossRef] [PubMed]

24. Schmitt, A.M.; Chang, H.Y. Long noncoding RNAs in cancer pathways. Cancer Cell 2016, 29, 452-463. [CrossRef]

25. Mitobe, Y.; Ikeda, K.; Suzuki, T.; Takagi, K.; Kawabata, H.; Horie-Inoue, K.; Inoue, S. ESR1-Stabilizing Long Noncoding RNA TMPO-AS1 Promotes Hormone-Refractory Breast Cancer Progression. Mol. Cell. Biol. 2019, 39. [CrossRef]

26. Yin, J.; Tu, G.; Peng, M.; Zeng, H.; Wan, X.; Qiao, Y.; Qin, Y.; Liu, M.; Luo, H. GPER-regulated lncRNA-Glu promotes glutamate secretion to enhance cellular invasion and metastasis in triple-negative breast cancer. FASEB J. Off. Publ. Fed. Am. Soc. Exp. Biol. 2020, 34, 4557-4572. [CrossRef] [PubMed]

27. Ma, T.; Liang, Y.; Li, Y.; Song, X.; Zhang, N.; Li, X.; Chen, B.; Zhao, W.; Wang, L.; Yang, Q. LncRNA LINP1 confers tamoxifen resistance and negatively regulated by ER signaling in breast cancer. Cell. Signal. 2020, 68, 109536. [CrossRef] [PubMed]

28. Wang, K.; Li, J.; Xiong, Y.-F.; Zeng, Z.; Zhang, X.; Li, H.-Y. A potential prognostic long noncoding RNA signature to predict recurrence among ER-positive breast cancer patients treated with tamoxifen. Sci. Rep. 2018, 8, 1-11. [CrossRef]

29. Hu, H.; Chen, Q.; Ding, S. LncRNA LINC01116 competes with miR-145 for the regulation of ESR1 expression in breast cancer. Eur. Rev. Med. Pharm. Sci. 2018, 22, 1987-1993.

30. Si, X.; Zang, R.; Zhang, E.; Liu, Y.; Shi, X.; Zhang, E.; Shao, L.; Li, A.; Yang, N.; Han, X.; et al. LncRNA H19 confers chemoresistance in ER $\alpha$-positive breast cancer through epigenetic silencing of the pro-apoptotic gene BIK. Oncotarget 2016, 7, 81452-81462. [CrossRef] 
31. Li, M.; Chai, H.F.; Peng, F.; Meng, Y.T.; Zhang, L.Z.; Zhang, L.; Zou, H.; Liang, Q.L.; Li, M.M.; Mao, K.G.; et al. Estrogen receptor $\beta$ upregulated by lncRNA-H19 to promote cancer stem-like properties in papillary thyroid carcinoma. Cell Death Dis. 2018, 9, 1120. [CrossRef] [PubMed]

32. Li, Y.; Jiang, B.; Wu, X.; Huang, Q.; Chen, W.; Zhu, H.; Qu, X.; Xie, L.; Ma, X.; Huang, G. Long non-coding RNA MIAT is estrogen-responsive and promotes estrogen-induced proliferation in ER-positive breast cancer cells. Biochem. Biophys. Res. Commun. 2018, 503, 45-50. [CrossRef] [PubMed]

33. Alipoor, F.J.; Asadi, M.H.; Torkzadeh-Mahani, M. MIAT lncRNA is overexpressed in breast cancer and its inhibition triggers senescence and G1 arrest in MCF7 cell line. J. Cell. Biochem. 2018, 119, 6470-6481. [CrossRef] [PubMed]

34. Ntini, E.; Louloupi, A.; Liz, J.; Muino, J.M.; Marsico, A.; Ørom, U.A.V. Long ncRNA A-ROD activates its target gene DKK1 at its release from chromatin. Nat. Commun. 2018, 9, 1-16. [CrossRef]

35. Deng, L.; Yang, H.; Tang, J.; Lin, Z.; Yin, A.; Gao, Y.; Wang, X.; Jiang, R.; Sun, B. Inhibition of MTA1 by ER $\alpha$ contributes to protection hepatocellular carcinoma from tumor proliferation and metastasis. J. Exp. Clin. Cancer Res. CR 2015, 34, 128. [CrossRef]

36. Miano, V.; Ferrero, G.; Reineri, S.; Caizzi, L.; Annaratone, L.; Ricci, L.; Cutrupi, S.; Castellano, I.; Cordero, F.; De Bortoli, M. Luminal long non-coding RNAs regulated by estrogen receptor alpha in a ligand-independent manner show functional roles in breast cancer. Oncotarget 2016, 7, 3201-3216. [CrossRef]

37. Mozdarani, H.; Ezzatizadeh, V.; Rahbar Parvaneh, R. The emerging role of the long non-coding RNA HOTAIR in breast cancer development and treatment. J. Transl. Med. 2020, 18, 1-15. [CrossRef]

38. Aiello, A.; Bacci, L.; Re, A.; Ripoli, C.; Pierconti, F.; Pinto, F.; Masetti, R.; Grassi, C.; Gaetano, C.; Bassi, P.F.; et al. MALAT1 and HOTAIR Long Non-Coding RNAs Play Opposite Role in Estrogen-Mediated Transcriptional Regulation in Prostate Cancer Cells. Sci. Rep. 2016, 6, 38414. [CrossRef]

39. Xue, X.; Yang, Y.A.; Zhang, A.; Fong, K.W.; Kim, J.; Song, B.; Li, S.; Zhao, J.C.; Yu, J. LncRNA HOTAIR enhances ER signaling and confers tamoxifen resistance in breast cancer. Oncogene 2016, 35, 2746-2755. [CrossRef]

40. Wang, M.; Li, Y.; Xiao, G.D.; Zheng, X.Q.; Wang, J.C.; Xu, C.W.; Qin, S.; Ren, H.; Tang, S.C.; Sun, X. H19 regulation of oestrogen induction of symmetric division is achieved by antagonizing Let-7c in breast cancer stem-like cells. Cell Prolif. 2019, 52, e12534. [CrossRef]

41. Fan, H.; Li, H.; Liu, H.; Li, P.; Jia, X.; Guo, P.; Yu, Q.; Li, X.; Guo, Y.; Li, X. Quercetin promotes long noncoding RNA lncSHGL expression via estrogen receptor $\alpha$ to suppress type 2 diabetes mellitus in mice. Res. Sq. 2020. [CrossRef]

42. Fu, X.; Zhu, J.; Zhang, L.; Shu, J. Long non-coding RNA NEAT1 promotes steatosis via enhancement of estrogen receptor alpha-mediated AQP7 expression in HepG2 cells. Artif. Cells Nanomed. Biotechnol. 2019, 47, 1782-1787. [CrossRef] [PubMed]

43. Lin, K.; Zhan, H.; Ma, J.; Xu, K.; Wu, R.; Zhou, C.; Lin, J. Silencing of SRA1 Regulates ER Expression and Attenuates the Growth of Stromal Cells in Ovarian Endometriosis. Reprod. Sci. 2017, 24, 836-843. [CrossRef] [PubMed]

44. Silva-Fisher, J.M.; Eteleeb, A.M.; Nielsen, T.; Perou, C.M.; Reis-Filho, J.S.; Ellis, M.J.; Mardis, E.R.; Maher, C.A. Discovery and characterization of late-stage breast cancer estrogen receptor alpha 1 bound long non-coding RNAs. In Proceedings of the AACR Annual Meeting, Washington, DC, USA, 1-5 April 2017; p. 2547.

45. Cairns, J.; Ingle, J.N.; Kalari, K.R.; Shepherd, L.E.; Kubo, M.; Goetz, M.P.; Weinshilboum, R.M.; Wang, L. The lncRNA MIR2052HG regulates ER $\alpha$ levels and aromatase inhibitor resistance through LMTK3 by recruiting EGR1. Breast Cancer Res. BCR 2019, 21, 47. [CrossRef]

46. Jiang, X.; Liu, Y.; Zhang, G.; Lin, S.; Yuan, N.; Wu, J.; Yan, X.; Ma, Y.; Ma, M. Acetyl-11-keto- $\beta$-boswellic Acid Inhibits Precancerous Breast Lesion MCF-10AT Cells via Regulation of LINC00707/miR-206 that Reduces Estrogen Receptor- $\alpha$. Cancer Manag. Res. 2020, 12, 2301-2314. [CrossRef]

47. Basak, P.; Chatterjee, S.; Weger, S.; Bruce, M.C.; Murphy, L.C.; Raouf, A. Estrogen regulates luminal progenitor cell differentiation through $\mathrm{H} 19$ gene expression. Endocr. Relat. Cancer 2015, 22, 505. [CrossRef]

48. Wang, Z.; Katsaros, D.; Biglia, N.; Shen, Y.; Loo, L.; Yu, X.; Lin, H.; Fu, Y.; Chu, W.M.; Fei, P.; et al. $\mathrm{ER} \alpha$ upregulates the expression of long non-coding RNA LINC00472 which suppresses the phosphorylation of NF-kB in breast cancer. Breast Cancer Res. Treat. 2019, 175, 353-368. [CrossRef]

49. Peng, W.-x.; Huang, J.-g.; Yang, L.; Gong, A.-h.; Mo, Y.-Y. Linc-RoR promotes MAPK/ERK signaling and confers estrogen-independent growth of breast cancer. Mol. Cancer 2017, 16, 161. [CrossRef] 
50. Ding, J.; Yeh, C.R.; Sun, Y.; Lin, C.; Chou, J.; Ou, Z.; Chang, C.; Qi, J.; Yeh, S. Estrogen receptor $\beta$ promotes renal cell carcinoma progression via regulating LncRNA HOTAIR-miR-138/200c/204/217 associated CeRNA network. Oncogene 2018, 37, 5037-5053. [CrossRef]

51. Chen, J.; Ge, B.; Wang, Y.; Ye, Y.; Zeng, S.; Huang, Z. Biochanin A promotes proliferation that involves a feedback loop of microRNA-375 and estrogen receptor alpha in breast cancer cells. Cell. Physiol. Biochem. 2015, 35, 639-646. [CrossRef]

52. Chen, J.; Zhang, X.; Wang, Y.; Ye, Y.; Huang, Z. Formononetin promotes proliferation that involves a feedback loop of microRNA-375 and estrogen receptor alpha in estrogen receptor-positive cells. Mol. Carcinog. 2016, 55, 312-319. [CrossRef] [PubMed]

53. Guo, Y.H.; Tang, F.Y.; Wang, Y.; Huang, W.J.; Tian, J.; Lu, H.L.; Xin, M.; Chen, J. Low concentration of formononetin promotes proliferation of estrogen receptor-positive cells through an ER $\alpha$-miR-375PTEN-ERK1/2-bcl-2 pathway. Oncotarget 2017, 8, 100045-100055. [CrossRef] [PubMed]

54. Chen, P.; Wang, H.; Yang, F.; Chen, H.; He, W.; Wang, J. Curcumin Promotes Osteosarcoma Cell Death by Activating miR-125a/ERR $\alpha$ Signal Pathway. J. Cell. Biochem. 2017, 118, 74-81. [CrossRef] [PubMed]

55. Zhao, X.; Li, X.; Ren, Q.; Tian, J.; Chen, J. Calycosin induces apoptosis in colorectal cancer cells, through modulating the ER $\beta / M i R-95$ and IGF-1R, PI3K/Akt signaling pathways. Gene 2016, 591, 123-128. [CrossRef] [PubMed]

56. Xiang, Y.; Lu, D.L.; Li, J.P.; Yu, C.X.; Zheng, D.L.; Huang, X.; Zhang, T.C. Myocardin inhibits estrogen receptor alpha-mediated proliferation of human breast cancer MCF-7 cells via regulating MicroRNA expression. IUBMB Life 2016, 68, 477-487. [CrossRef]

57. Martin, E.C.; Conger, A.K.; Yan, T.J.; Hoang, V.T.; Miller, D.F.; Buechlein, A.; Burow, M.E. MicroRNA-335-5p and-3p synergize to inhibit estrogen receptor alpha expression and promote tamoxifen resistance. FEBS Lett. 2017, 591, 382-392. [CrossRef]

58. Mobini, K.; Tamaddon, G.; Fardid, R.; Keshavarzi, M.; Mohammadi-Bardbori, A. Aryl hydrocarbon-estrogen alpha receptor-dependent expression of $\mathrm{miR}-206, \mathrm{miR}-27 \mathrm{~b}$, and miR-133a suppress cell proliferation and migration in MCF-7 cells. J. Biochem. Mol. Toxicol. 2019, 33, e22304. [CrossRef]

59. Petrovic, N.; Davidovic, R.; Jovanovic-Cupic, S.; Krajnovic, M.; Lukic, S.; Petrovic, M.; Roganovic, J. Changes in miR-221/222 Levels in Invasive and In Situ Carcinomas of the Breast: Differences in Association with Estrogen Receptor and TIMP3 Expression Levels. Mol. Diagn. Ther. 2016, 20, 603-615. [CrossRef]

60. Liu, B.W.; Yu, Z.H.; Chen, A.X.; Chi, J.R.; Ge, J.; Yu, Y.; Cao, X.C. Estrogen receptor- $\alpha-m i R-1271-S N A I 2$ feedback loop regulates transforming growth factor- $\beta$-induced breast cancer progression. J. Exp. Clin. Cancer Res. CR 2019, 38, 109. [CrossRef]

61. Lettlova, S.; Brynychova, V.; Blecha, J.; Vrana, D.; Vondrusova, M.; Soucek, P.; Truksa, J. MiR-301a-3p Suppresses Estrogen Signaling by Directly Inhibiting ESR1 in ER $\alpha$ Positive Breast Cancer. Cell. Physiol. Biochem. Int. J. Exp. Cell. Physiol. Biochem. Pharmacol. 2018, 46, 2601-2615. [CrossRef]

62. Ya, G.; Wang, H.; Ma, Y.; Hu, A.; Ma, Y.; Hu, J.; Yu, Y. Serum miR-129 functions as a biomarker for colorectal cancer by targeting estrogen receptor (ER) $\beta$. Die Pharm. 2017, 72, 107-112. [CrossRef]

63. Ma, F.; Feng, Y.; Li, W.; Li, Z.; Liu, T.; Li, L. miR-148a Suppresses estrogen-induced viability and migration of breast cancer cells via inhibition of estrogen receptor $\alpha$ expression. Exp. Ther. Med. 2017, 13, 2515-2522. [CrossRef]

64. Liu, X.; Zhang, L.; Tong, Y.; Yu, M.; Wang, M.; Dong, D.; Shao, J.; Zhang, F.; Niu, R.; Zhou, Y. MicroRNA-22 inhibits proliferation, invasion and metastasis of breast cancer cells through targeting truncated neurokinin-1 receptor and ER $\alpha$. Life Sci. 2019, 217, 57-69. [CrossRef] [PubMed]

65. Mansoori, B.; Mohammadi, A.; Gjerstorff, M.F.; Shirjang, S.; Asadzadeh, Z.; Khaze, V.; Baradaran, B. $\mathrm{miR}-142-3 \mathrm{p}$ is a tumor suppressor that inhibits estrogen receptor expression in ER-positive breast cancer. J. Cell. Physiol. 2019, 234, 16043-16053. [CrossRef] [PubMed]

66. Aakula, A.; Leivonen, S.K.; Hintsanen, P.; Aittokallio, T.; Ceder, Y.; Børresen-Dale, A.L.; Perälä, M.; Östling, P.; Kallioniemi, O. MicroRNA-135b regulates ER $\alpha$, AR and HIF1AN and affects breast and prostate cancer cell growth. Mol. Oncol. 2015, 9, 1287-1300. [CrossRef]

67. Han, L.; Liu, B.; Jiang, L.; Liu, J.; Han, S. MicroRNA-497 downregulation contributes to cell proliferation, migration, and invasion of estrogen receptor alpha negative breast cancer by targeting estrogen-related receptor alpha. Tumor Biol. 2016, 37, 13205-13214. [CrossRef] [PubMed] 
68. Lin, J.; Wang, L.; Gao, J.; Zhu, S. MiR-203 inhibits estrogen-induced viability, migration and invasion of estrogen receptor $\alpha$-positive breast cancer cells. Exp. Ther. Med. 2017, 14, 2702-2708. [CrossRef]

69. Bao, W.; Zhang, Y.; Li, S.; Fan, Q.; Qiu, M.; Wang, Y.; Li, Y.; Ji, X.; Yang, Y.; Sang, Z.; et al. miR-107-5p promotes tumor proliferation and invasion by targeting estrogen receptor- $\alpha$ in endometrial carcinoma. Oncol. Rep. 2019, 41, 1575-1585. [CrossRef]

70. Deng, J.; Wang, W.; Yu, G.; Ma, X. MicroRNA-195 inhibits epithelial-mesenchymal transition by targeting G protein-coupled estrogen receptor 1 in endometrial carcinoma. Mol. Med. Rep. 2019, 20, 4023-4032. [CrossRef]

71. Chen, J.-J.; Tang, Y.-S.; Huang, S.-F.; Ai, J.-G.; Wang, H.-X.; Zhang, L.-P. HBx protein-induced upregulation of microRNA-221 promotes aberrant proliferation in HBV-related hepatocellular carcinoma by targeting estrogen receptor- $\alpha$. Oncol. Rep. 2015, 33, 792-798. [CrossRef]

72. Meng, D.; Li, Z.; Ma, X.; Fu, L.; Qin, G. MicroRNA-1280 modulates cell growth and invasion of thyroid carcinoma through targeting estrogen receptor $\alpha$. Cell. Mol. Biol. 2016, 62, 1-6.

73. Alexandrova, E.; Lamberti, J.; Saggese, P.; Pecoraro, G.; Memoli, D.; Cappa, V.M.; Ravo, M.; Iorio, R.; Tarallo, R.; Rizzo, F.; et al. Small Non-Coding RNA Profiling Identifies miR-181a-5p as a Mediator of Estrogen Receptor Beta-Induced Inhibition of Cholesterol Biosynthesis in Triple-Negative Breast Cancer. Cells 2020, 9, 874. [CrossRef] [PubMed]

74. Ma, H.; Tian, T.; Liang, S.; Liu, X.; Shen, H.; Xia, M.; Liu, X.; Zhang, W.; Wang, L.; Chen, S.; et al. Estrogen receptor-mediated miR-486-5p regulation of OLFM4 expression in ovarian cancer. Oncotarget 2016, 7, 10594-10605. [CrossRef] [PubMed]

75. Lü, M.; Ding, K.; Zhang, G.; Yin, M.; Yao, G.; Tian, H.; Lian, J.; Liu, L.; Liang, M.; Zhu, T.; et al. MicroRNA-320a sensitizes tamoxifen-resistant breast cancer cells to tamoxifen by targeting ARPP-19 and ERR $\gamma$. Sci. Rep. 2015, 5, 8735. [CrossRef]

76. Liu, Z.-R.; Song, Y.; Wan, L.-H.; Zhang, Y.-Y.; Zhou, L.-M. Over-expression of miR-451a can enhance the sensitivity of breast cancer cells to tamoxifen by regulating 14-3-3 $\zeta$, estrogen receptor $\alpha$, and autophagy. Life Sci. 2016, 149, 104-113. [CrossRef] [PubMed]

77. Ljepoja, B.; García-Roman, J.; Sommer, A.-K.; Wagner, E.; Roidl, A. MiRNA-27a sensitizes breast cancer cells to treatment with Selective Estrogen Receptor Modulators. Breast 2019, 43, 31-38. [CrossRef]

78. Zheng, L.; Meng, X.; Li, X.; Zhang, Y.; Li, C.; Xiang, C.; Xing, Y.; Xia, Y.; Xi, T. miR-125a-3p inhibits ER $\alpha$ transactivation and overrides tamoxifen resistance by targeting CDK3 in estrogen receptor-positive breast cancer. FASEB J. Off. Publ. Fed. Am. Soc. Exp. Biol. 2018, 32, 588-600. [CrossRef]

79. Yu, T.; Yu, H.R.; Sun, J.Y.; Zhao, Z.; Li, S.; Zhang, X.F.; Liao, Z.X.; Cui, M.K.; Li, J.; Li, C.; et al. miR-1271 inhibits ER $\alpha$ expression and confers letrozole resistance in breast cancer. Oncotarget 2017, 8, 107134-107148. [CrossRef]

80. Jiang, C.F.; Li, D.M.; Shi, Z.M.; Wang, L.; Liu, M.M.; Ge, X.; Liu, X.; Qian, Y.C.; Wen, Y.Y.; Zhen, L.L.; et al. Estrogen regulates miRNA expression: Implication of estrogen receptor and miR-124/AKT2 in tumor growth and angiogenesis. Oncotarget 2016, 7, 36940-36955. [CrossRef]

81. Huang, R.; Li, J.; Pan, F.; Zhang, B.; Yao, Y. The activation of GPER inhibits cells proliferation, invasion and EMT of triple-negative breast cancer via CD151/miR-199a-3p bio-axis. Am. J. Transl. Res. 2020, 12, 32.

82. Vidal-Gómez, X.; Pérez-Cremades, D.; Mompeón, A.; Dantas, A.P.; Novella, S.; Hermenegildo, C. MicroRNA as crucial regulators of gene expression in estradiol-treated human endothelial cells. Cell. Physiol. Biochem. 2018, 45, 1878-1892. [CrossRef] [PubMed]

83. Sanawar, R.; Dan, V.M.; Santhoshkumar, T.R.; Kumar, R.; Pillai, M.R. Estrogen receptor- $\alpha$ regulation of microRNA-590 targets FAM171A1-A modifier of breast cancer invasiveness. Oncogenesis 2019, 8, 1-13. [CrossRef] [PubMed]

84. Ali, H.O.; Arroyo, A.B.; González-Conejero, R.; Stavik, B.; Iversen, N.; Sandset, P.M.; Skretting, G. The role of micro RNA-27a/b and micro RNA-494 in estrogen-mediated downregulation of tissue factor pathway inhibitor $\alpha$. J. Thromb. Haemost. 2016, 14, 1226-1237. [CrossRef] [PubMed]

85. Teng, Y.; Radde, B.N.; Litchfield, L.M.; Ivanova, M.M.; Prough, R.A.; Clark, B.J.; Doll, M.A.; Hein, D.W.; Klinge, C.M. Dehydroepiandrosterone Activation of G-protein-coupled Estrogen Receptor Rapidly Stimulates MicroRNA-21 Transcription in Human Hepatocellular Carcinoma Cells. J. Biol. Chem. 2015, 290, 15799-15811. [CrossRef]

86. Ou, Z.; Wang, Y.; Chen, J.; Tao, L.; Zuo, L.; Sahasrabudhe, D.; Joseph, J.; Wang, L.; Yeh, S. Estrogen receptor $\beta$ promotes bladder cancer growth and invasion via alteration of miR-92a/DAB2IP signals. Exp. Mol. Med. 2018, 50, 1-11. [CrossRef] 
87. Vivacqua, A.; Sebastiani, A.; Miglietta, A.M.; Rigiracciolo, D.C.; Cirillo, F.; Galli, G.R.; Talia, M.; Santolla, M.F.; Lappano, R.; Giordano, F.; et al. miR-338-3p Is Regulated by Estrogens through GPER in Breast Cancer Cells and Cancer-Associated Fibroblasts (CAFs). Cells 2018, 7, 203. [CrossRef]

88. Piperigkou, Z.; Franchi, M.; Goette, M.; Karamanos, N.K. Estrogen receptor beta as epigenetic mediator of miR-10b and miR-145 in mammary cancer. Matrix Biol. 2017, 64, 94-111. [CrossRef]

89. Nguyen-Vu, T.; Wang, J.; Mesmar, F.; Mukhopadhyay, S.; Saxena, A.; McCollum, C.W.; Gustafsson, J.; Bondesson, M.; Williams, C. Estrogen receptor beta reduces colon cancer metastasis through a novel miR-205-PROX1 mechanism. Oncotarget 2016, 7, 42159-42171. [CrossRef]

90. Chen, Y.; Wu, N.; Liu, L.; Dong, H.; Wu, C. Correlation between microRNA-21, microRNA-206 and estrogen receptor, progesterone receptor, human epidermal growth factor receptor 2 in breast cancer. Clin. Biochem. 2019, 71, 52-57. [CrossRef]

91. Howard, E.W.; Yang, X. microRNA Regulation in Estrogen Receptor-Positive Breast Cancer and Endocrine Therapy. Biol. Proced. Online 2018, 20, 17. [CrossRef]

92. Xu, D.; Takeshita, F.; Hino, Y.; Fukunaga, S.; Kudo, Y.; Tamaki, A.; Matsunaga, J.; Takahashi, R.U.; Takata, T.; Shimamoto, A.; et al. miR-22 represses cancer progression by inducing cellular senescence. J. Cell Biol. 2011, 193, 409-424. [CrossRef] [PubMed]

93. Adams, B.D.; Cowee, D.M.; White, B.A. The role of miR-206 in the epidermal growth factor (EGF) induced repression of estrogen receptor- $\alpha(E R \alpha)$ signaling and a luminal phenotype in MCF-7 breast cancer cells. Mol. Endocrinol. 2009, 23, 1215-1230. [CrossRef] [PubMed]

94. Gao, T.; Deng, M.; Wang, Q. Mi RNA-320a inhibits trophoblast cell invasion by targeting estrogen-related receptor-gamma. J. Obstet. Gynaecol. Res. 2018, 44, 756-763. [CrossRef] [PubMed]

95. Liu, R.H.; Meng, Q.; Shi, Y.P.; Xu, H.S. Regulatory role of microRNA-320a in the proliferation, migration, invasion, and apoptosis of trophoblasts and endothelial cells by targeting estrogen-related receptor $\gamma$. J. Cell. Physiol. 2019, 234, 682-691. [CrossRef] [PubMed]

96. Sheng, B.; Yuan, Y.; Liu, X.; Zhang, Y.; Liu, H.; Shen, X.; Liu, B.; Chang, L. Protective effect of estrogen against intervertebral disc degeneration is attenuated by miR-221 through targeting estrogen receptor $\alpha$. Acta Biochim. Biophys. Sin. 2018, 50, 345-354. [CrossRef]

97. Cai, Z.; Li, K.; Yang, K.; Luo, D.; Xu, H. Suppression of miR-203-3p inhibits lipopolysaccharide induced human intervertebral disc inflammation and degeneration through upregulating estrogen receptor $\alpha$. Gene Ther. 2020. [CrossRef] [PubMed]

98. Guo, Y.; Tian, L.; Du, X.; Deng, Z. MiR-203 regulates estrogen receptor $\alpha$ and cartilage degradation in IL-1 $\beta$-stimulated chondrocytes. J. Bone Miner. Metab. 2020, 38, 346-356. [CrossRef] [PubMed]

99. Tian, L.; Su, Z.; Ma, X.; Wang, F.; Guo, Y. Inhibition of miR-203 ameliorates osteoarthritis cartilage degradation in the postmenopausal rat model: Involvement of estrogen receptor $\alpha$. Hum. Gene Ther. Clin. Dev. 2019, 30, 160-168. [CrossRef]

100. Lin, Y.; Xiao, L.; Zhang, Y.; Li, P.; Wu, Y.; Lin, Y. Mir-26b-3p regulates osteoblast differentiation via targeting estrogen receptor $\alpha$. Genomics 2019, 111, 1089-1096. [CrossRef]

101. He, K.; Niu, G.; Gao, J.; Liu, J.-X.; Qu, H. MicroRNA-92 expression may be associated with reduced estrogen receptor $\beta 1 \mathrm{mRNA}$ levels in cervical portion of uterosacral ligaments in women with pelvic organ prolapse. Eur. J. Obstet. Gynecol. Reprod. Biol. 2016, 198, 94-99. [CrossRef]

102. Fiorillo, A.A.; Heier, C.R.; Huang, Y.-F.; Tully, C.B.; Punga, T.; Punga, A.R. Estrogen Receptor, Inflammatory, and FOXO Transcription Factors Regulate Expression of Myasthenia Gravis-Associated Circulating microRNAs. Front. Immunol. 2020, 11, 151. [CrossRef] [PubMed]

103. Zhu, X.; Yang, Y.; Han, T.; Yin, G.; Gao, P.; Ni, Y.; Su, X.; Liu, Y.; Yao, Y. Suppression of microRNA-18a expression inhibits invasion and promotes apoptosis of human trophoblast cells by targeting the estrogen receptor $\alpha$ gene. Mol. Med. Rep. 2015, 12, 2701-2706. [CrossRef] [PubMed]

104. Yuan, L.; Tang, C.; Li, D.; Yang, Z. MicroRNA-18a expression in female coronary heart disease and regulatory mechanism on endothelial cell by targeting estrogen receptor. J. Cardiovasc. Pharmacol. 2018, 72, 277-284. [CrossRef] [PubMed]

105. Xiao, Y.; Li, B.; Liu, J. MicroRNA-148a inhibition protects against ovariectomy-induced osteoporosis through PI3K/AKT signaling by estrogen receptor $\alpha$. Mol. Med. Rep. 2018, 17, 7789-7796. [CrossRef] [PubMed]

106. Stary, C.M.; Xu, L.; Li, L.; Sun, X.; Ouyang, Y.B.; Xiong, X.; Zhao, J.; Giffard, R.G. Inhibition of miR-181a protects female mice from transient focal cerebral ischemia by targeting astrocyte estrogen receptor- $\alpha$. Mol. Cell. Neurosci. 2017, 82, 118-125. [CrossRef] [PubMed] 
107. Wang, Q.; Xu, C.; Zhao, Y.; Xu, Z.; Zhang, Y.; Jiang, J.; Yan, B.; Gu, D.; Wu, M.; Wang, Y.; et al. miR-26b-3p Regulates Human Umbilical Cord-Derived Mesenchymal Stem Cell Proliferation by Targeting Estrogen Receptor. Stem Cells Dev. 2016, 25, 415-426. [CrossRef]

108. Astuti, I.; Torizal, G.; Sa'adah, N.; Oktriani, R.; Wardana, T.; Aryandono, T.; Mubarika, S. Resistance to doxorubicin correlated with dysregulation of microRNA-451 and P-glyoprotein, caspase 3, estrogen Receptor on Breast Cancer cell line. J. Med. Sci. 2019, 51, 282-291.

109. Xiao, Y.; Liu, G.; Sun, Y.; Gao, Y.; Ouyang, X.; Chang, C.; Gong, L.; Yeh, S. Targeting the estrogen receptor alpha $(E R \alpha)$-mediated circ-SMG1.72/miR-141-3p/Gelsolin signaling to better suppress the HCC cell invasion. Oncogene 2020, 39, 2493-2508. [CrossRef]

110. Tribollet, V.; Barenton, B.; Kroiss, A.; Vincent, S.; Zhang, L.; Forcet, C.; Cerutti, C.; Périan, S.; Allioli, N.; Samarut, J.; et al. miR-135a Inhibits the Invasion of Cancer Cells via Suppression of ERR $\alpha$. PLoS ONE 2016, 11, e0156445. [CrossRef]

111. Li, X.; Peng, B.; Zhu, X.; Wang, P.; Sun, K.; Lei, X.; Yang, L. MiR-210-3p inhibits osteogenic differentiation and promotes adipogenic differentiation correlated with Wnt signaling in ER $\alpha$-deficient rBMSCs. J. Cell. Physiol. 2019, 234, 23475-23484. [CrossRef]

112. Panic, A.; Stanimirovic, J.; Obradovic, M.; Zafirovic, S.; Sudar-Milovanovic, E.; Petrovic, N.; Isenovic, E.R. $17 \beta$-estradiol inhibits hepatic iNOS via the activation of the estrogen receptor ER- $\alpha$ and inhibition of erk1/2-mir-221 axis. J. Biol. Regul. Homeost. Agents 2018, 32, 1369-1377. [PubMed]

113. Elliot, S.; Periera-Simon, S.; Xia, X.; Catanuto, P.; Rubio, G.; Shahzeidi, S.; El Salem, F.; Shapiro, J.; Briegel, K.; Korach, K.S.; et al. MicroRNA let-7 Downregulates Ligand-Independent Estrogen Receptor-mediated Male-Predominant Pulmonary Fibrosis. Am. J. Respir. Crit. Care Med. 2019, 200, 1246-1257. [CrossRef] [PubMed]

114. Wang, X.; Fang, L. Advances in circular RNAs and their roles in breast Cancer. J. Exp. Clin. Cancer Res. 2018, 37, 206. [CrossRef] [PubMed]

115. Lu, L. Identification of circular RNAs as a promising new class of diagnostic biomarkers for human breast cancer. Oncotarget 2017, 8, 44096-44107. [CrossRef] [PubMed]

116. Nair, A.A.; Niu, N.; Tang, X.; Thompson, K.J.; Wang, L.; Kocher, J.P.; Subramanian, S.; Kalari, K.R. Circular RNAs and their associations with breast cancer subtypes. Oncotarget 2016, 7, 80967-80979. [CrossRef]

117. Brown, J.; Shah, P.; Vo, J.; Xiao, L.; Niknafs, Y.; Cao, X.; Chinnaiyan, A. Noninvasive identification of lineage-specific circular RNA for ER-positive breast cancer. Am. Soc. Clin. Oncol. 2020. [CrossRef]

118. Yuan, C.; Zhou, L.; Zhang, L.; Yin, K.; Peng, J.; Sha, R.; Zhang, S.; Xu, Y.; Sheng, X.; Wang, Y.; et al. Identification and integrated analysis of key differentially expressed circular RNAs in ER-positive subtype breast cancer. Epigenomics 2019, 11, 297-321. [CrossRef]

119. Petrović, N. miR-21 Might be Involved in Breast Cancer Promotion and Invasion Rather than in Initial Events of Breast Cancer Development. Mol. Diagn. Ther. 2016, 20,97-110. [CrossRef]

120. Mills, J.N.; Rutkovsky, A.C.; Giordano, A. Mechanisms of resistance in estrogen receptor positive breast cancer: Overcoming resistance to tamoxifen/aromatase inhibitors. Curr. Opin. Pharmacol. 2018, 41, 59-65. [CrossRef]

(C) 2020 by the authors. Licensee MDPI, Basel, Switzerland. This article is an open access article distributed under the terms and conditions of the Creative Commons Attribution (CC BY) license (http://creativecommons.org/licenses/by/4.0/). 